\title{
Critical Review of North Korean Women and Children's Health, 2000-2019: Physical and Mental Health Challenges with a Focus on Gender
}

\author{
AMANDA WRIGHT* ${ }^{*}$ LYNN PYUN** EUNHEE HA** • JUNGSUN KIM ${ }^{* * * *} \bullet$ \\ HAE SOON KIM ${ }^{* * * *} \cdot$ SEOK HYANG KIM ${ }^{* * * * * *} \cdot$ INSOO OH ${ }^{* * * * * *} \cdot$ EUN MEE KIM ${ }^{* * * * * * *}$
}

\begin{abstract}
Women account for over eighty percent of recent North Korean defectors arriving in South Korea, yet there is dearth of gender-based research. Given the speed with which the dialogue on denuclearization with the Democratic People's Republic of Korea (DPRK, North Korea) has progressed since 2017, there is a surprising gap in research on possible health threats. If sanctions are eased, interactions with these previously isolated people will increase leading to potential health problems. This article reviews studies published since 2000 to understand physical and mental health faced in DPRK, among North Korean defectors to South Korea, and to provide policy recommendations. A content analysis of ninety studies found that mental health challenges are severe for North Korean defectors, and that women suffer differently than men during defection and its aftermath. We recommend a more nuanced and gendered approach for future research in order to devise tangible solutions to improve the health of North Koreans in general, and defector women and children in particular.
\end{abstract}

Keywords: North Korea, DPRK, women's and children's health, North Korean defectors, mental health, maternal and child health

*Lead author, Ph.D. Candidate, Department of International Studies, GSIS, Ewha Womans University; amandarosewright@gmail.com

**Visiting Professor, Department of International Studies, GSIS, Ewha Womans University; pyun@ewha.ac.kr

***Professor, College of Medicine, Ewha Womans University; eunheeha@ewha.ac.kr

****Professor, Department of Sociology, College of Social Sciences, Ewha Womans University; jungsun@ewha.ac.kr

*****Professor, Department of Pediatrics, College of Medicine, Ewha Womans University; hyesk@ewha.ac.kr

$* * * * * *$ Professor, Department of North Korean Studies, College of Social Sciences, Ewha Womans University; feelfree@ewha.ac.kr

*******Professor, Department of Education, College of Education, Ewha Womans University; insoo@ewha.ac.kr

$* * * * * * * *$ Corresponding author, Professor, Department of International Studies, GSIS, Ewha Womans University; emkim@ewha.ac.kr

DOI: 10.16934/isr.20.2.201912.95 


\section{INTRODUCTION}

There is an urgent need to better understand the health of North Korean women and children, whose health status has been largely neglected in research and policy. In 2018, the share of women among the North Korean defectors entering South Korea reached an all-time high of eighty-five percent (Ministry of Unification 2019). With improvements in relations between the Republic of Korea (ROK, South Korea) and the Democratic People's Republic of Korea (DPRK, North Korea), there is a growing need to understand the health of those in the DPRK, in transit, and defectors to South Korea. Given the possibility that interaction among the people of the two Koreas will increase in the near future, having an accurate assessment of the current health on the peninsula is vital.

We need to understand the reclusive nation of DPRK from a humanitarian perspective as well as in light of recent negotiations for denuclearization which could result in a sudden easing of sanctions against the DPRK, and increased interaction of people that could have unpredictable health consequences for both Koreas, not to mention other neighboring countries.

This article critically examines studies published in English or Korean on the topic of North Korean women and children's health from 2000-2019. Women and children are grouped into three categories depending on their location, stage of defection, and settlement: (1) women and children in the DPRK; (2) women and children in transit out of the DPRK; and (3) women and children from the DPRK who have entered South Korea as defectors. We also reviewed reports on the health of women and children in the DPRK and among the defector population, which were published by the United Nations and other international organizations to understand the broader context.

Content analysis of the articles was conducted to examine shared patterns and differences in a systematic manner. Three broad questions guided the analysis: (1) do different groups of North Korean women and children show differences in health patterns; (2) is there any significant difference in studies published in Korean vs. English; and (3) implications for further research and policy recommendations.

\section{RESEARCH METHODOLOGY}

The health status of North Korean women and children is an intrinsically important topic for basic human rights, and since improvement in relations and increased interactions between the two Koreas will lead to short and long-term health consequences. There were only a few studies on North Korean health, and even fewer on women and children, despite the number of women defectors and 
children entering South Korea has rapidly risen in recent years. We will focus on Korean and English sources due to lack of relevant studies in other languages. For example, keyword search on Web of Science for "North Korea Health" returned three hundred and thirty-seven articles, of which only one study was written in neither English nor Korean. Articles published since 2000 were reviewed, since earlier studies had a heavy focus on the 1990s' famine and its impact on health in the DPRK with relatively little attention to broader health issues.

\section{English Language Studies}

We reviewed English language studies on the health of North Korean women and children in three stages. First, we searched the database PubMed, since this is acknowledged by the biomedical research community as "the primary tool" (Lu 2011, 2) as the most widely used database for studies related to health (Sood and Ghosh 2006). Initial search was conducted using phrases such as, "North Korean women and child health in North Korea" (7 results), "North Korean defector health" (5 results), "North Korean women's health" (5 results), and "DPRK women health" (4 results). Second, the list of references of the studies selected through the PubMed search was used to screen for additional studies. And, finally Google scholar was searched for studies with a broader context including migration and trafficking. We excluded studies from the review if they did not have a specific focus on the health of North Korean women and children.

There were relatively few English studies that dealt with North Koreans directly, which was most likely due to the need for state approval for empirical research in the DPRK. Thus, most studies were about North Korean defectors. The People's Republic of China (China) is an important part of many defectors' migration journey, and a few of the studies are based in China. Although the North Korean defector population is very small in Japan, one article was included that compared North Korean defectors in Japan to Japanese workers of similar socio-economic status as well as to North Korean defectors in South Korea.

Four review articles were included in our analysis. These studies provided useful data on the growth of children in South and North Korea, growth and nutrition of North Korean children, mental health of defectors, and an overall review of health in the DPRK (Park et al. 2019; Lee 2017; Lee, Lee and Park 2017; Schwekendiek and Pak 2009).

In total we reviewed forty-one articles in English, which included twenty-two on mental health, sixteen on physical health, and three on both mental and physical health. There were four review articles among the forty-one, which were useful for cross-reference. 


\section{Korean Language Studies}

Korean language studies were reviewed for the period of 2000-2019 using the following databases (DBs): Korean Studies Information Service System (KISS) with a focus on peer-reviewed journals; Research Information Sharing Service (RISS) with a focus on Master's and Ph.D. theses; and (3) online database of the Korean National Assembly (NANET) which was focused on government reports. Searching these DBs is a standard methodology in review studies for Korean research literature regarding health-related topics (Kwon, Kim and Nam 2019; Sim 2018; Kim, Cho and Jeon 2014).

We selected studies for review as follows: First, the DBs were searched with different combinations of keywords on DPRK women's health which included North Korea, women, and health. Second, keywords describing DPRK refugees were used for the search - i.e., defecting from North Korea, North Korean defectors, and Saeteomin (North Korean settlers in South Korea) -- in conjunction with the keywords of North Korea, women and health. Third, we reviewed titles and abstracts of the studies to decide if the paper actually dealt with DPRK women's health. If there was any doubt, we included the article for a full review. In addition, studies that dealt with North Korean defectors as a whole, but mentioned female/children as a meaningful unit of analysis were included. Fourth, studies that were included in the list of references of the studies selected for this review were also examined. Finally, a total of ten review articles were included in our analysis, which met the above standards of inclusion and exclusion.

In total, a total of forty-nine articles written in Korean, including ten review articles, were analyzed. A quick review of the studies indicated that there were relatively few studies on the DPRK and defector women and children's health, and there was a dearth of studies that had a gender focus. Even some studies that covered both women and men's health data pointed out that further female-focused research is needed (Ree, Ku and Han 2011; Keum 2015; Lim, Lee and Yang 2017).

\section{KEY TRENDS IN THE STUDIES ON NORTH KOREAN AND NORTH KOREAN DEFECTOR WOMEN AND CHILDREN'S HEALTH}

A content analysis was conducted for all the articles. Since the topic of women and children's health has been largely neglected in the study of DPRK residents and North Korean defectors, we started with a breakdown based on the subject group - i.e., (1) North Korean women and children; (2) North Korean women and children in transit (migration); and (3) North Korean defectors who 
have settled in South Korea. There were relatively few studies on the defectors who have settled in countries outside of South Korea, and thus, we limited our search to those settled in South Korea (see Figure 1 for selection process).

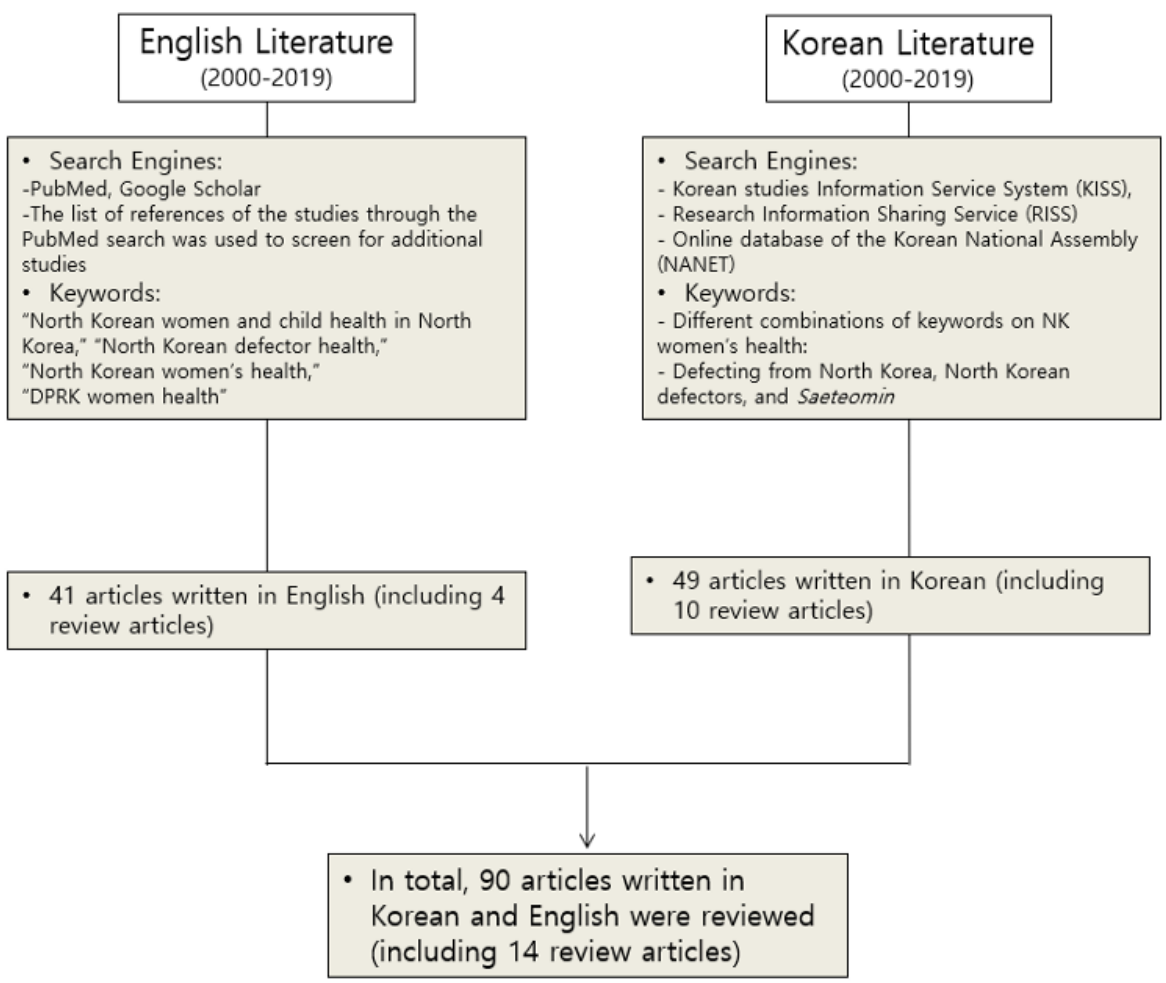

FIGURE 1. SELECTION PROCESS OF STUDIES REVIEWED

First, we noted that the studies written in English and Korean were different in terms of content and subject group. The studies written in English had a much stronger focus on defectors compared to DPRK residents (Figure 2). Additionally, a comparison of mental vs. physical health studies in English vs. Korean showed that English sources were more on mental health, while there were more Korean studies on physical health (Figure 3). 


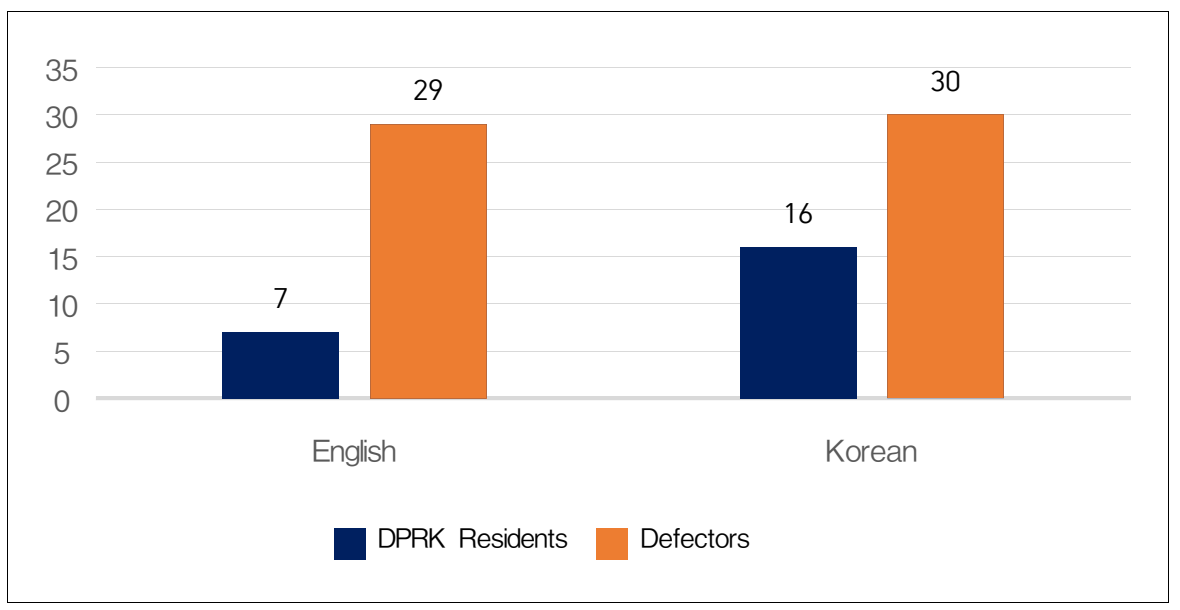

FIGURE 2. NUMBER OF STUDIES ON DPRKVS. DEFECTORS, BY LNGUAGE

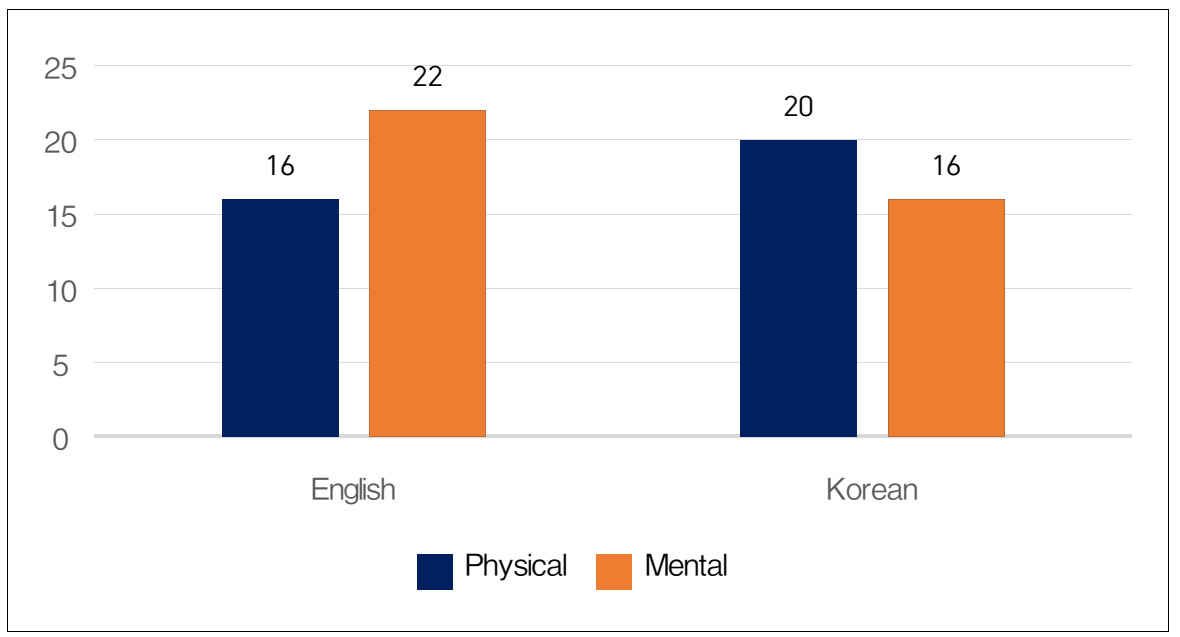

\section{FIGURE 3. NUMBER OF STUDIES ON PHYSICAL VS. MENTAL HEALTH, BY LANGUAGE}

In both Korean and English studies, more studies were about North Korean defectors to South Korea than people in DPRK, although Korean sources had a few more studies on DPRK residents compared to English. The reason for a relatively small number of English studies on DPRK is likely due to the need to acquire the DPRK government's permit for empirical research, which would have been more prohibitive to researchers using English. Table 1 provides a breakdown of the categories of studies reviewed. 
TABLE 1. BREAKDOWN OF STUDIES REVIEWED BY STUDY POPULATION AND HEALTH TYPE

\begin{tabular}{|c|c|c|c|c|c|c|}
\hline & & $\begin{array}{c}\text { DPRK } \\
\text { Residents }\end{array}$ & In Transit & $\begin{array}{l}\text { North Korean } \\
\text { Defectors }\end{array}$ & $\begin{array}{c}\text { DPRK } \\
\text { Residents \& } \\
\text { Defectors }\end{array}$ & Sub-Total \\
\hline \multirow{3}{*}{$\begin{array}{l}\text { English } \\
\text { Language } \\
\text { Studies }\end{array}$} & Physical Health & 7 & & 8 (1 Review) & 1 (1 Review) & 16 \\
\hline & Mental Health & & 2 & 20 (1 Review) & & 22 \\
\hline & $\begin{array}{l}\text { Physical \& Mental } \\
\text { Health }\end{array}$ & & 1 & 1 & 1 (1 Review) & 3 \\
\hline & Sub-Total & 7 & 3 & 29 & 2 & 41 \\
\hline \multirow{3}{*}{$\begin{array}{l}\text { Korean } \\
\text { Language } \\
\text { Studies }\end{array}$} & Physical Health & 14 & & 5 & 1 & 20 \\
\hline & Mental Health & & 1 & 15 (1 Review) & & 16 \\
\hline & $\begin{array}{l}\text { Physical \& Mental } \\
\text { Health }\end{array}$ & 2 & & 10 (9 Reviews) & 1 & 13 \\
\hline \multicolumn{2}{|r|}{ Sub-Total } & 16 & 1 & 30 & 2 & 49 \\
\hline \multicolumn{2}{|r|}{ Total } & 23 & 4 & 59 & 4 & 90 \\
\hline
\end{tabular}

It was noteworthy that English sources had a relatively small number of studies on physical health compared to mental health. This could be due to the unavailability of disaggregate data on the physical health of North Korean women and children, and/or greater severity of mental health challenges for this group. Further research is required to examine this issue.

\section{Physical Health of Women and Children}

Analysis from the DPRK official data, and common international data sources, including reports from the UN, World Bank (WB), UNICEF, World Health Organization (WHO), and the World Food Programme (WFP) have indicated that empirical evidence and data on health problems in the DPRK may be underreported since official statistics have been limited to geographical areas where the government allows access. In spite of these limitations, studies revealed that the health status of North and South Koreans are strikingly different, with nearly a ten-year gap in life expectancy in 2018, up from just one-year in 1993 (Bahk, Ezzati and Khang 2018), and residents of DPRK and defectors have significantly shorter average heights (Pak 2010; Pak 2004).

We noted that there are relatively few studies on physical health. In English sources, we found that in gynecological health, forty-two percent of defectors receive cervical cancer screenings (also known as Pap smears or Pap tests), far lower than their South Korean peers for whom about seventy percent were screened (Park, Kim, Yang, Lee and Park 2018). Kim, Kim, and Chung (2017) found that defectors, who were concerned about cancer and had knowledge of free cervical cancer screening programs, were more likely to have 
Pap tests. We also noted that although female defectors who had Pap tests were relatively small compared to their South Korean counterparts, they were much greater than the DPRK women for whom only six percent received such screenings (Tran et al. 2011a). A study conducted in the DPRK showed that although there was very little rural vs. urban difference among healthcare providers in their knowledge and practices on cervical cancer and screenings, both areas suffered from inefficiencies and misunderstandings (Tran et al. 2011b). The study on defectors found that ten to twenty percent reported menstrual problems like amenorrhea, changes in the amount of blood clot, polymenorrhea, hypomenorrhea, and menorrhagia, and that these were correlated with anxiety, depression, and somatization (Kim, Kim, and Kim 2017). A recent study of sixty-one female defectors found that a mobile video program could significantly increase knowledge and behavioral confidence regarding vaginitis and cervical cancer (Lee and Shin 2018).

A few studies were conducted on the dental health of children in DPRK, ranging from six to thirteen years old, which showed that dental caries were positively associated with having sweet snacks and were reduced after the children participated in a state sponsored intervention program, but the authors noted that this could have been due to the loss of primary teeth (Tarvonen et al. 2016; Tarvonen et al. 2017).

North Korean defectors showed that their stature was smaller than South Korean counterparts even after spending years in South Korea, since most have defected when they were adults (Cho, Lee, Koh, Kim and Kim 2015; Choi, Park and Joung 2010; Pak 2010; Pak 2004). Height, weight, and body surface area were found to be significantly lower across gender and age, except among female defectors over 50 years old (Cho et al. 2015). An examination of defector children and adolescents upon their entry to South Korea shows similar results (Pak 2010). North Korean defectors also appear to have weaker muscle strength (Cho et al. 2015).

Korean language studies showed a diversity of findings among different surveys of North Korean women and children (Park, Lee and Kim 2014). First-hand data collected from a 2004 study showed that South Koreans are taller and heavier than those in the DPRK, even from before the famine; and the health situation has aggravated in the DPRK since the late 1980s, based on a study of Hanawon ${ }^{1}$ residents' Body Mass Index (BMI) (Moon et al. 2004). Another study showed that age was associated with a low risk for Subclinical Hypothyroidism $(\mathrm{SCH})$, the opposite result from South Koreans, which is possibly due to severe famine during their period of growth (Kim et al. 2012). A 2015 study using medical records showed a high occurrence of Hepatitis B and C, parasite, tuberculosis (TB), anemia, sexually-transmitted diseases (STD), and human papilloma virus (HPV) compared to South Koreans (Ahn, Ryou, and Kim 2015; 
Moon et al. 2015). A recent study by Wee (2018) showed that a 1981-1990 cohort of women were smaller by $1.1-1.2 \mathrm{~cm}$ (male $1.9-2.0 \mathrm{~cm}$ ) than those from 1966-1970, who finished growing before the great famine in the DPRK. ${ }^{2}$ It is interesting to note that although we limited our search to studies published since 2000 , traces of the great famine were still felt in the health status of North Korean women, children and defectors in South Korea.

\section{Mental Health of Women and Children}

Most of the English sources were about mental health showing that over half of North Koreans examined exhibited significant mental health problems (Cha, Surkan, Kim, Yoon, Robinson, Cardozo and Lee 2018; Lee, Min and Jeon 2009; Lee, Lee, Chun, Lee and Yoon 2001; Jeon 2000).

Many studies showed that depression is experienced by a large number of defectors (Cha, et al. 2018; Kim, Kim and Kim 2017; Nam, Kim, DeVylder and Song 2016; Jeon et al. 2009; Lee, Min and Jeon 2009; Lee et al. 2001; Jeon 2000). A few studies went beyond the presence of the symptom of depression and examined its correlates. Um, Chi, Kim, Palinkas and Kim (2015) found that perceived discrimination was positively correlated with depression. Another study found that income was correlated with depression - i.e., families with very low family income of under 1.0 million Korean Won showed six times greater likelihood of depression compared to families with moderately low income of under 1.5 million Korean Won (Jeon et al. 2009). On the other hand, Kim, Kim, Choi and Nam (2017) did not find a significant effect between sexual victimization and depression or post-traumatic stress disorder (PTSD). A study in China of defectors in protective facilities found that females had higher levels of depression, anxiety and schizophrenia compared to males (Yu and Jeon 2008).

Another study showed that defectors with PTSD symptom dropped dramatically in a follow-up study conducted seven years later (Jeon, Eom and Min 2013). The number of traumatic experiences was not always found to be a clear and significant indicator of PTSD (Park, Jun, Lee, Kim, Lee, Yoo and Kim 2015; Jeon et al. 2005). Rather, Park et al. $(2015,81)$ found that the "role of alexithymia in the development of PTSD is likely to be more prominent in victims of multiple traumatic experiences." In a study of female defectors, the most prevalent symptom of PTSD was somatization, which was linked with having an income under 1.0 million Korean Won (Shin and Lee 2015).

Experiencing trauma, including the violation of their economic or political human rights, was found to have a significant negative relationship with mental health (Cha et al. 2018; Lim and Han 2016; Kim, Cho and Kim 2015; Lee et al. 2001). The majority of defectors experienced at least one type of trauma, with some studies reporting over ninety percent experiencing trauma (Lee et al. 2001). 
Such trauma could be part of the reason why adolescent defectors may greatly internalize their problems and have significantly higher levels than their South Korean peers for anxiety, depression and social dysfunction (Lee, Shin and Lim 2012). Jeon, Yu, Cho, and Eom (2008) found a drop in the trauma rate of recent defectors compared to new defectors to South Korea based on a questionnaire conducted in 2004.

Although most studies did not examine suicidal ideation, income was shown to have a significant effect on suicidal ideation (Kim, Kim, Cho and Nam 2017), while income was shown to be strongly correlated with depression (Jeon et al. 2009), which has previously been noted to be a predictor of suicide (Stack 2000). Comparing suicidal ideation of defectors with South Koreans, Shin, Lee, and Park $(2016,595)$ found that defectors who "had longer durations of stays abroad, more than two escape attempts from North Korea, and longer durations of stays after entering South Korea all showed higher rates of suicidal ideation."

Studies also showed that acculturation is a significant problem since stress from integration into their host community can also decrease self-efficacy and mental well-being (Lim and Han 2016; Kim, Cho and Kim 2015).

It is important to understand health from a gendered approach in both mental and physical health, especially in light of the notorious trafficking of North Korean women (Choe 2019; Ochab 2019). Traffickers are said to use rape as well as physical and psychological abuse to control these women, although the long-term effects have not yet been studied thoroughly (Kim, Yun, Park and Williams 2009). Thus, a more nuanced, longer-term, and gender-based research during the experience of leaving the DPRK, in transit as well as settlement in South Korea should be conducted in future research.

A few studies recommended solutions for dealing with mental health challenges. Resilience was shown to be very important for defectors' mental health (Lim and Han 2016; Kim, Cho and Kim 2015), and ego resiliency was shown to mediate acculturation stress among the young defectors (Kim, Cho and Kim 2015). Socio-cultural adjustment has been found to be positively associated with psychological adjustment (Kraeh, Froese and Kim 2016). Um, Chi, Kim, Palinkas and Kim (2015) found higher levels of adaptation correlated with lower levels of depression, and Emery, Lee and Kang (2015) found that higher levels of family order and attachment to both parents were associated with lower levels of self-reported depression in a study of defector youth and adolescents born in China by defector mothers.

Length of stay in South Korea was generally positively correlated with improved mental health (Pak 2010; Pak 2004). However, not much information was provided of the length of stay if it was interrupted with transit through a third country. In some studies, defector women's mental health improved with a stay of over four years in South Korea (Cho et al. 2015), while other studies showed 
that mental health variables are negatively correlated with the length of stay (Shin, Lee and Park 2016; Jeon et al. 2005).

In sum, studies written in English investigated a range of psychological characteristics, with depression and PTSD among the most pressing mental health challenges facing the defector community, but did not provide much in the way of policy recommendations (Cha et al. 2018; Kim, Kim and Kim 2017; Nam et al. 2016; Emery, Lee and Kang 2015; Park et al. 2015; Um et al. 2015).

Korean language studies were largely on refugee women and children and assumed that the subjects would have incurred severe trauma in the process of leaving the DPRK, and/or migrating through a third country, and settling in South Korea as a defector. Many studies showed that defectors have overall poor mental health, and this was more acute for women due to sexual violence and trafficking (Yang and Yun 2017; Kang and Chang 2009; Kang 2005; Cho and Jeon 2005). Another study found that 45.5 percent of female defectors had suicidal thoughts in the past year, which was much higher than the South Korean adult average of 3.7 percent (Kim et al. 2013).

An overwhelming share of female defectors (86.4\%) had sexual dysfunction, compared to 50-60 percent of South Korean women (Rhee, Ku, and Han 2013). About half of female defectors had depression (48.5\% for women defectors vs. $21.5 \%$ for South Korean women) (Kim, Ryu, and Kim 2014). However, there was an unexpected finding that married women currently living with a spouse had more mental health difficulties than single women or married women not living with a spouse (Cho and Jeon 2005). Exposure to sexual violence and trafficking was negatively associated with anxiety and fear (Yeun 2005). Long-term adaption was more strongly correlated with depression and anxiety compared to PTSD itself (Cho and Kim 2010), while PTSD mattered more than trauma itself in determining sexual autonomy (Lee and Kim 2019). It was found that defectors with 1-3 years since settlement had the worst levels of depression and guilt (Kim 2012).

It is important to study the defector children's mental health. A growing number of defector children are increasingly born in third countries, and not in the DPRK. According to statistics from the Ministry of Education in 2017, 64.8 percent of elementary defector children were born in third countries. They face additional difficulties since they were born in challenging circumstances that made their parental and family environment very difficult for a normal childhood (Lee 2012). Since most mothers entered South Korea before their children came, the children tended to develop unstable attachment to their mothers once they were reunited, and the trauma and depression experienced by many female defectors during the defection process had a negative impact on their children's mental health (Do 2018). Children often did not receive proper school education in third countries, so they had difficulty adapting to South Korean schools. They 
were also exposed to rejection by South Korean students since they had poor Korean language ability(Eun and Cho 2015). Considering these aggravated mental health problems for defector children, Noh and Oh (2018) recommended that school-based mental health programs be established to enhance defector children's mental health.

In sum, although it is true that female defectors suffer severely from mental health challenges, it seems that what matters more is what comes after the trauma than the experience itself. Married female defectors tend to show a higher tendency for mental health problems, possibly due to double marriage or spousal abuse. Thus, more nuanced studies are needed that take into consideration the full context of their life circumstances. In addition, several studies indicated that there are acculturation challenges in settling in South Korea. Although one may assume that the defectors would face less problems in settling in South Korea since they speak the same language, the reality was different. Not only has the Korean language changed in DPRK since the two Koreas were divided which made it challenging for the defectors to easily settle in South Korea, but there were reports of harassment and mistreatment of defectors which contributed to their mental health challenges. Thus, more in-depth studies of defectors' experience settling in South Korea including real and perceived discrimination is needed.

We noted that studies on North Korean women and children's health did not provide much in terms of healthcare delivery and policy recommendations in both the English and Korean studies. Only two Korean studies provided policy recommendations (Hwang 2012; Park and Lee 2013). More multidisciplinary studies are needed since the health challenges are complex and show both physical and mental health difficulties, along with complex circumstances that contributed to the ill health. Perceived discrimination and acculturation stress hurt defectors' mental health, therefore it is important to support defectors with depression, and also to educate South Koreans in order to promote a more welcoming host community environment (Lim and Han 2016; Um et al. 2015; Jeon 2000). Another study called for improvements in how South Korea handles challenges of its entire population - i.e., society-wide problems of high suicide rate and alcohol consumption-since they also affect the defector community (Kim, Kim, Choi and Nam 2017).

\section{CONCLUSION}

Our study began with an alarming note that there is a lack of understanding about the health status of North Korean women and children, even when the number of women defecting to South Korea has risen dramatically in recent years. Around eighty percent of defectors arriving in South Korea in the 
last five years, and seventy-two percent of all arrivals in the last twenty years are female (Ministry of Unification 2019). This is due to two reasons: first, women dominate in the thriving jangmadang (black market), where they can get access to the network of defection brokers and information about the outside world (Maresca 2017; Ernst and Jurowetzki 2016); and second, growing preference for female defectors over males in China, the most popular transit country. Male defectors are increasingly viewed as a source of crime and violence, while females are welcomed as petty laborers and potential spouses to Chinese locals (Yoon, Park, and Im 2014).

Our review of both English and Korean studies showed some interesting patterns. First, there was a greater focus on North Korean defectors to South Korea than women and children in the DPRK. This was likely due to the limits of disaggregated data in the DPRK and the DPRK government's reluctance to allow for empirical research. Second, the impact of the great famine in the DPRK was evident in the small stature and other health status of North Koreans compared to both their South Korean counterparts as well as to North Koreans who were not affected by the famine. Third, there was a clear gender difference in health among the people in the DPRK and defectors, which suggests that gender-based research is needed (Pak 2010; Jeon et al. 2008). In particular, some mental health challenges were significantly higher in female than male defectors, but did not go further to examine why this difference occurred from a gender-based analysis. A gendered approach is also needed for defector women in transit since trafficking is a serious problem (Choe 2019; Ochab 2019). Trafficking has serious consequences on both physical and mental health challenges, and thorough research is needed to examine the current status of the problem, causes, and possible solutions (Kim, Yun, Park and Williams 2009).

Since there is very little known about the health status of North Korean women, it is difficult to assess whether the studies reviewed in this paper reflect correctly the status of mental and physical health of North Korean women. However, empirical studies on North Korean defector women showed that a high level of stress was related to their migration experience and adjusting in the South Korean society. What is clear is that we need more empirical research on the health of North Korean women in the DPRK as well as those in transit and settlement in South Korea. In addition, this paper highlights the importance of including mental health as well as physical health in assessing the health of the North Korean and North Korean defector women.

As the DPRK is in discussions with the US, South Korea, and China, the time for the easing and removal of sanctions against the DPRK may come very quickly, not allowing for much preparation. Our study suggests that we need to have better empirical research on various health variables in the DPRK and defectors from both a humanitarian perspective, and from the viewpoint of 
working with the DPRK through global, regional and inter-Korean cooperation. Our review has shown that health challenges faced by North Koreans and defectors are complex, and warrants that further research to be multidisciplinary to tackle the compounded nature of health challenges and solutions. The complexities of international politics, migration, mental and physical health, integration, abuse, and trafficking cannot be looked at in isolation. Finally, with the growing number of North Korean women who are defecting to South Korea, it is critical that more research focus on the health challenges of women and children from a gendered approach in order to understand the context and determinants of their health challenges and to develop tangible policy recommendations to improve their health.

\section{REFERENCES}

$<$ English Sources $>$

Bahk, Jinwook, Majid Ezzati, and Young-Ho Khang. 2018. "The Life Expectancy Gap Between North and South Korea from 1993 to 2008." European Journal of Public Health 28(5): 830-835.

Cha, Jiho, Pamela J. Surkan, Jaeshin Kim, Isabel A. Yoon, Courtland Robinson, and Hayoung Lee. 2018. "Human Rights as Political Determinants of Health: A Retrospective Study of North Korean Refugees." American Journal of Preventive Medicine 55(2): 271-279.

Choe, Sang-Hun. 2019. "After Fleeing North Korea, Women Get Trapped as Cybersex Slaves in China," in The New York Times, last modified Sept. 13, 2019. Accessed Oct. 20, 2019, https://www.nytimes.com/2019/09/13/ world/asia/north-korea-cybersex-china.html

Choi, Seul Ki, Sang Min Park, and Hyojee Joung. 2010. "Still Life with Less: North Korean Young Adult Defectors in South Korea Show Continued Poor Nutrition and Physique." Nutrition Research and Practice 4(2): 136-141.

Cho, Sun Wook, So Hee Lee, Eun Sil Koh, Si Eun Kim, and Seok Joong Kim. 2015. "Characteristics of Body Composition and Muscle Strength of North Korean Refugees during South Korean Stay." Endocrinology and Metabolism 30(4): 551-556.

Emery, Clifton R., Jung Yun Lee, and Chulhee Kang. 2015. "Life after the Pan and the Fire: Depression, Order, Attachment, and the Legacy of Abuse among North Korean Refugee Youth and Adolescent Children of North Korean Refugees." Child Abuse and Neglect 45: 90-100.

Ernst, Maximilian and Roman Jurowetzki. 2016. "Satellite Data, Women Defectors and Black Markets in North Korea: A Quantitative Study of the North 
Korean Informal Sector Using Night-Time Lights Satellite Imagery." North Korean Review 12(2): 64-83.

Goe, Leon C., Mary Anne S. Baysac, Knox H Todd, John A Linton. 2005. "Assessing the Prevalence of Dental Caries among Elementary School Children in North Korea: A Cross ${ }^{-}$sectional Survey in the Kangwon Province." International Journal of Dental Hygiene 3(2): 112-116.

Jeon, Bong-Hee, Moon-Doo Kim, Seong-Chul Hong, Na-Ri Kim, Chang-In Lee, Young-Sook Kwan, Joon-Hyuk Park, Jaehwan Chung, Hanul Chong, Eun-Kyung Jwa, Min-Ho Bae, Sanghee Kim, Bora Yoo, Jun-Hwa Lee, Mi-Yeul Hyun, Mi-Jeong Yang, and Duk-Soo Kim. 2009. "Prevalence and Correlates of Depressive Symptoms among North Korean Defectors Living in South Korea for More than One Year." Psychiatry Investigation 6(3): 122-130.

Jeon, Woo-Taek. 2000. "Issues and Problems of Adaptation of North Korean defectors to South Korean society: An In-depth Interview Study with 32 Defectors." Yonsei Medical Journal 41(3): 362-371.

Jeon, Woo-Taek, Jin-Sup Eom, and Sung Kil Min. 2013. "A 7-Year Follow-Up Study on the Mental Health of North Korean Defectors in South Korea." Journal of Traumatic Stress 26(2): 158-164.

Jeon, Woo Taek, Chang Hyung Hong, Chang Ho Lee, Dong Kee Kim, Mooyoung Han, and Sung Kil Min. 2005. "Correlation between Traumatic Events and Posttraumatic Stress Disorder among North Korean Defectors in South Korea." Journal of Traumatic Stress 18(2):147-54.

Jeon, Woo-Teak, Shi-Eun Yu, Young-A Cho, and Jin-Sup Eom. 2008. "Traumatic

Experiences and Mental Health of North Korean Refugees in South Korea." Psychiatry Investigation 5(4): 213-220

Kim, Eunyoung, Minwoo Yun, Mirang Park, and Hue Williams. 2009. "Cross

Border North Korean Women Trafficking and Victimization between

North Korea and China: An Ethnographic Case Study." International Journal of Law Crime and Justice 37(4): 154-169.

Kim, Hyo Hyun, Yu Jin Lee, Ha Kyoung Kim, Jung Eun Kim, Seog Ju Kim, Seung-Min Bae, and Seong-Jin Cho. 2011. "Prevalence and Correlates of Psychiatric Symptoms in North Korean Defectors." Psychiatry Investigation 8(3): 179-185.

Kim, Hyun Kyoung, Hee Sook Kim, and Seog Ju Kim. 2017. "Association of Anxiety, Depression, and Somatization with Menstrual Problems among North Korean Women Defectors in South Korea." Psychiatry Investigation 14(6): 727-733.

Kim, Jae Yop, Hee Jin Kim, Kwonho Choi, and Boyoung Nam. 2017. "Mental Health Conditions Among North Korean Female Refugee Victims of Sexual Violence." International Migration 55(2): 68-79. 
Kim, Kyounghae, Soohyun Kim, and Yoonkyung Chung. 2017. "A Qualitative Study Exploring Factors Associated with Pap Test Use among North Korean Refugees." Health Care for Women International 38(10): 1115-1129.

Kim, Yeunhee J., Cho, Young-A, and Hyun Ah Kim. 2015. "A Mediation Effect of Ego Resiliency Between Stresses and Mental Health of North Korean Refugee Youth in South Korea." Child and Adolescent Social Work Journal 32(5): 481-490.

Kraeh, Albert, Fabian Jintae Froese, and Sin Gon Kim. 2016. "Does Sociocultural and Psychological Adjustment Influence Physical Health? The Case of North Korean Refugees in South Korea." International Journal of Intercultural Relations 51: 54-60.

Lee, Chang-ho, Sung-kil Min, Woo-taek Jeon, Mika Kigawa, and Michiya Sugawara. 2009. "Mental Health and Quality of Life of North Korean Defectors Living in Japan." Asian Journal of Psychiatry 2(3): 95-99.

Lee, Min Kyeong and Gisoo Shin. 2018. "A Mobile Video Intervention for Women's Health of North Korean Defectors." Public Health Nursing 35(6): 558-562.

Lee, Soo-Kyung. 2017. "North Korean Children: Nutrition and Growth." Annals of Pediatric Endocrinology \& Metabolism 22(4): 231-239.

Lee, Yunhwan Lee, Myung Ken Lee, Ki Hong Chun, Yeon Kyung Lee, and Soo Jin Yoon. 2001. "Trauma Experience of North Korean Refugees in China." American Journal of Preventive Medicine 20(3): 225-229.

Lee, Yeeun, Minji Lee, and Subin Park. 2017. "Mental Health Status of North Korean Refugees in South Korea and Risk and Protective Factors: a 10-year Review of the Literature." European Journal of Psychotraumatology 8(2): 1-13.

Lee, Young Mun Lee, Ok Ja Shin, and Myung Ho Lim. 2012. "The Psychological Problems of North Korean Adolescent Refugees Living in South Korea." Psychiatry Investigation 9(3): 217-222.

Lim, So-Hee, and Sang-Sook Han. 2016. "A Predictive Model on North Korean

Refugees' Adaptation to South Korean Society: Resilience in Response to Psychological Trauma." Asian Nursing Research 10(2): 164-172.

Lu, Zhiyong. 2011. "PubMed and Beyond: a Survey of Web Tools for Searching Biomedical Literature." Database 2011: 1-13.

Maresca, Thomas. 2017. "Why the Overwhelming Majority of North Korean Defectors Are Women," in USA Today, last modified December 10, 2017. Accessed December 14, 2019, https://www.usatoday.com/story/news/world/ 2017/12/10/most-defectors-north-korea-women/923072001/

Ministry of Unification. 2019. "Policy on North Korean Defectors." Accessed October 13, 2019, https://www.unikorea.go.kr/eng_unikorea/relations/statistics/ 
defectors/

Nam, Boyoung, Jae Yop Kim, Jordan E. DeVylder, and Ahyoung Song. 2016. "Family Functioning, Resilience, and Depression among North Korean Refugees." Psychiatry Research 245: 451-457.

Ochab, Ewelina U. 2019. "Trafficking of North Korean Women in China," in Forbes, last modified July 1, 2019, accessed October 21, 2019, https://www. forbes.com/sites/ewelinaochab/2019/07/01/trafficking-of-north-korean-wo men-in- china/\#51a8bf477af0

Pak, Sunyoung. 2010. "The Growth Status of North Korean Refugee Children and Adolescents from 6 to 19 Years of Age." Economics \& Human Biology 8(3): 385-395.

Pak, Sunyoung. 2004. "The Biological Standard of Living in the Two Koreas." Economics \& Human Biology 2(3): 511-521.

Park, John, Ah-Young Lim, Hyung-Soon Ahn, Andrew I Kim, Soyoung Choi, David H.W. Oh, Owen Lee-Park, Sharon Y Kim, Sun Jae Jung, Jesse B Bump, Rifat Atun, Hee Young Shin, Kee B. Park. 2019. "Systematic Review of Evidence on Public Health in the Democratic People's Republic of Korea." BMJ Global Health 4(2): 1-9.

Park, Juhyun, Jin Yong Jun, Yu Jin Lee, Soohyun Kim, So-Hee Lee, So Young Yoo, and Seog Ju Kim. 2015. "The Association Between Alexithymia and Posttraumatic Stress Symptoms following Multiple Exposures to Traumatic Events in North Korean Refugees." Journal of Psychosomatic Research 78(1): 77-81.

Park, Jeongok, Hee Sook Kim, Wonhee Yang, Hae Won Lee, and Sang Min Park. 2018. "Cervical Cancer Screening and Its Associated Factors Among North Korean Defectors Living in South Korea." Journal of Immigrant and Minority Health 20(1): 66-72.

Rim, Hui Yong, Su Huan Kim, Byong Chel Sim, Hae Yong Gang, Ho Yong Kim, Yong Ran Kim, Rak Chel Kim, Mun Hui Yang, and Sang Pil Kim. 2008. "Effect of Iron Fortification of Nursery Complementary Food on Iron Status of Infants in the DPRKorea." Asia Pacific Journal of Clinical Nutrition 17(2): 264-269.

Schwekendiek, Daniel and Sunyoung Pak. 2009. "Recent Growth of Children in the Two Koreas: A Meta-Analysis." Economics \& Human Biology 7(1): 109-112.

Shin, Gisoo and Suk Jeong Lee. 2015. "Mental Health and PTSD in Female North Korean Refugees." Health Care for Women International 36(4): 409-423.

Stack, Steven. 2000. "Suicide: A 15-year Review of the Sociological Literature. Part I: Cultural and Economic Factors." Suicide and Life-Threatening Behavior 30(2):145-62. 
Sood, Amit and Amit Ghosh. 2006. "Literature Search Using PubMed: An Essential Tool for Practicing Evidence- Based Medicine." Journal of Association of Physicians of India 54(4):303-308.

Tarvonen, Pirkko-Liisa, Kirsi Sipila, GS Yang, JK Kim, M-L Lamidi, and Arho L. Suominen. 2016. "Comparison of two preventive interventions on dental caries among children in Democratic People's Republic of Korea." International Journal of Dental Hygiene 14(4):301-306.

Tarvonen, Pirkko-Liisa, Arho L. Suominen, GS Yang, YS Ri, and Kirsi Sipila. 2017. "Association between Oral Health Habits and Dental Caries among Children in Pyongyang, Democratic People's Republic of Korea." International Journal of Dental Hygiene 15(4): 136-142.

Tran, Nguyen Toan, Song Il, Choe, Richard Taylor, Won Suk Ko, Hae Suk Pyo, and Hyon Chol So. 2011a. "Knowledge, Attitude and Practice (KAP) concerning Cervical Cancer and Screening among Rural and Urban Women in Six Provinces of the Democratic People's Republic of Korea." Asian Pacific Journal of Cancer Prevention 12(11): 3029-3033.

Tran, Nguyen Toan, Song Il, Choe, Richard Taylor, Won Suk Ko, Hae Suk Pyo, and Hyon Chol So. 2011b. "Knowledge, Attitude and Practice (KAP) concerning Cervical Cancer and Screening among Rural and Urban Women in Six Provinces of the Democratic People's Republic of Korea." Asian Pacific Journal of Cancer Prevention 12(11): 3023-3028.

Um, Mee Young, Iris Chi, Hee Jin Kim, Lawrence A. Palinkas, and Jae Yop Kim. 2015. "Correlates of Depressive Symptoms among North Korean Refugees Adapting to South Korean Society: The Moderating role of Perceived Discrimination." Social Science \& Medicine 131: 107-113.

Yu, Shi-Eun and Woo-Teak Jeon. "Mental Health of North Korean Refugees in Protective Facilities in China." Psychiatry Investigation 5(2): 70-77.

$<$ Korean Sources $>$

Ahn, Sun Young, Sung Hyeok Ryou, and Suk Bae Kim. 2015. "Clinical

Characteristics Defectors from North Korea Visiting a Single Tertiary Hospital in South Korea(단일 3차 의료기관에 내원한 탈북자 환자들의 임상적 특징)." Korean Journal of Medicine 89(1): 54-63.

Cho, Kyung Sook. 2016a. "Infant/Child Mortality and Humanitarian Aids to North Korea(북한의 영아 및 아동 사망률과 대북 인도적 지원)." Health and Social Welfare Review 36(3): 485-515.

Cho, Kyung Sook. 2016b. "Major Health Indicators in South and North Korea:

With Special Reference to West and East Germany(통일 독일의 사례를 통해 본 남북한 주요 건강지표의 현황과 전망)." Health and Social Welfare Review 36(2): 33-56.

Cho, Young A and Woo Taek Jeon. 2005. "A Qualitative Study of North Korea 
Women Defectors` Adaptation to South Korean Life(탈북 여성들의 남한 사회 적응 문제)." The Korean Journal of Woman Psychology 10(1): 17-35.

Cho, Young A and Yeun Hee Kim. 2010. "Predictors of Mental Health Risks in Newly Resettled North Korean Refugee Women(초기 거주 북한이탈여성 의 정신건강 고위험군 예측요인)." The Korean Journal of Woman Psychology 15(3): 509-527.

Do, Ji-wan, 2018. “Qualitative Case-study on Transit of North Korean Defector's Children Born in the Third Countries and Their Experience of Family Relationship(제 3국 출생 북한이탈청소년의 이주와 가족관계 경험에 관 한 질적 사례연구).” (Master's dissertation, Korea University).

Eun, Jihyun and Youngha Cho. 2015. "A Study on the Perceptions of School Bullying by Young North Korean Defectors(탈북청소년들의 학교폭력에 대한 인식 경향 연구)." Studies on Korean Youth 26(1) 51-77.

Hwang, Na Mi. 2010. "Identification of Health Indicators Based on the 2008 Census of Population in DPR Korea(2008 북한 인구센서스를 통해 본 북 한 보건지표 평가)." Health and Welfare Policy Forum 169:76-88.

Hwang, Na Mi. 2012. "Achieving the Millennium Development Goals and Challenges Facing the Health Sector in North Korea(북한의 UN 새천년 개발목표(MDGs) 달성도 및 우선순위보건과제)." Health and Welfare Policy Forum 192: 74-87.

Jeon, Jeung-hee, Kwon Myoung-Ok, Kim Hyewon, Jung Yoomi, Hwang Se-min, and Ha Beomman. 2018. "Sexual Knowledge, Sexual Attitude, Stress Coping, and Resilience of North Korean Female Defectors(북한이탈여성 의 성지식, 성태도, 스트레스 대처와 자아탄력성)." Journal of Military Nursing Research 36(1): 22-34.

Jung, Yu-Jin and Bit-Nae Choi. "Effects of the Length of Stay in Transit Country and Forcible Repatriation Experience on the Mental Health of North Korean Refugee Women Resettled in South Korea: BPSI-NKR Analysis (탈북에서 입국까지의 기간 및 북송경험이 탈북 여성의 심리상태에 미 치는 영향)." Korean Journal of Woman Psychology 22(1): 47-67.

Kang, Cha Yeun. 2005. "The Stress Copying Style of the Female North Korean Refugees in China(재중 탈북여성들의 스트레스 대처방식)." The Korean Journal of Woman Psychology 10(1): 61-80.

Kang, Sook Jung and Chang Ho Lee. 2009. "Psychological Understanding of Saeteomin through MMPI Results: Based on Gayang-Dong Saeteomin (MMPI검사결과를 통한 새터민의 심리상담적 접근: 가양동 새터민을 중심으로)." Korea Journal of Counseling 10(1): 235-250.

Keum, Myoung Ja. 2015. "The Trend of Research related to North Korean, North Korean Refugee, and Unification in Korean Psychology: Analysis of Research in 14 Korean Journals of Psychology:2000-2013(한국심리학회 
의 북한 및 북한이탈주민 관련 연구 동향)." Korean Journal of Psychology: General 34(2): 541-566.

Kim, Hee Kyung. 2010. "The Relations between Defense Mechanism and Mental Health Problems of North Korean Female Refugees(탈북 여성의 방어기 제와 정신건강의 관계)." The Korean Journal of Woman Psychology 15(1):155-173.

Kim, Hee Kyung. 2012. "Comparison of the Influence of Depressed Mood, Parenting Guilt, and Parenting Stress on Parenting Behaviors in North Korean Women Refugees and South Korean Women(탈북 여성과 남한 여 성의 우울감, 양육 죄책감 및 양육 스트레스가 양육 행동에 미치는 영향 력의 차이)." The Korean Journal of Woman Psychology 17(4): 535-558.

Kim, Hee Sook, Haewon Lee, and Sang Min Park. 2015. "Survey of North

Korea's Maternal and Newborn Health Management through North Korean Defectors(북한이탈주민 설문조사를 통해 본 북한의 모성과 신 생아 건강관리 실태)." Journal of the Korean Society of Maternal and Child Health 19(1): 37-46.

Kim, Hye Ryun. 2007. "Overview of the Nutritional Status and Policy Directions of Supporting Children`s Nutrition in North Korea(북한 주민의 영양상태 현황과 정책 과제)." Health and Welfare Policy Forum 132: 24-34.

Kim, Hyun Kyoung, Hee Sook Kim, and Seog Ju Kim. 2016. "Difference of

Traumatic Experience according to Menstrual Regularity among North Korean Woman Refugees in South Korea(북한이탈 여성의 월경규칙성 에 따른 외상경험 차이)." Journal of the Korean Society of Maternal and Child Health 20(1): 43-53.

Kim, Jae Yeop, Won Jung Ryu, and Ji Min Kim. 2014. "A Study on Daily Life

Stress and Depression -Moderating Effect of Traumatic Event(탈북여성 의 생활사건스트레스와 우울에 관한 연구 -외상경험의 조절효과)." Korean Journal of Family Social Work 46: 85-107.

Kim, Jae Yop, and Won Jung Ryu. 2016. "A Study on Cycle of Child Abuse among North Korean Refugee Women: Focused on Aggravating Effects of Spouse Abuse(탈북여성의 아동학대 피해 및 가해에 관한 연구: -배우자 폭력의 가중효과를 중심으로)." Korean Journal of Family Social Work 52: 375-399.

Kim, Jae Yop, Kwon Ho Choi, Ji Hun Chae, and Hyun Ju Hwang. 2013. "Life

Stress, Social Support and Suicidal Ideation of North Korean Refugee Women in South Korea(탈북여성의 일상생활 스트레스가 자살생각에 미치는 영향과 사회적 지지의 조절효과)." Korean Journal of Social Welfare Studies 44(2): 33-56.

Kim, Joo Hyung, Sol Ah Park, Nam Hoon Kim, Jae Hee Ahn, Yoon Jung Kim, Myoung Jin Cho, Yoon Jung Lee, Hye Jin Yoo, Hee Young Kim, Ji A Seo, Nan Hee Kim, and Kyung Mook Chol. 2012. "Thyroid Dysfunction of 
North Korean Women Living in South Korea, Focusing on Subclinical Hypothyroidism(남한에 거주하는 북한 이주민 여성의 갑상선기능 이상: 무증상 갑상선기능저하증을 중심으로)." Endocrinology and Metabolism 27(3): 200-207.

Kim, Min, Sunhee Cho, and Gyeong-suk Jeon. 2014. "Barriers and Strategies to Adaptation among Korean Male Nursing Students: A Systematic Review." Korean Journal of Stress Research 22: 109-119.

Kim, Seok Hyang and Eun Ju Lee. 2012. "The Trend and the Task of North Korean Women Researches(북한여성 연구의 동향과 과제)." North Korean Studies Review 16(2): 229-268.

Kim, Seok Hyang and Min Ju Park. 2016. "The Practice of Women and Social Structure on the Reproductive Sphere in North Korea: The Reproductionrelated Legislations and Women's Experience (북한 내 재생산 영역의 사 회구조와 여성의 실천)." Women's Studies Review 33(1): 99-134.

Kim, Soo Youn. 2010. "The Study on Impact of North Korea's Famine on Fertility and Reproductive Health(기근이 북한 여성의 출산 및 생식보건에 미친 영향)." (Ph.D. dissertation, Seoul National University.).

Kwak, Su-Jin. 2014. "A Study on Birth Experience of North Korean Women(북 한 여성의 출산 경험 연구)." (Master's dissertation, University of North Korean Studies).

Kwon, Mi Kyoung, Jin Sun Kim, and Sang In Nam. 2019. "Research Trend on Adult Suicide in South Korea." Crisisonomy 15(9): 17-37.

Lee, Gee Dong. 2011. "The Consciousness of 'March of Suffering' Generation and Regime Change." Journal of North Korean Studies 36(2): 8-39.

Lee, Ki-Hyun, 2012. "Strategic Approaches to China's North Korean Defector Policy." The Korean Journal of National Unification 21(2): 119-142.

Lee, Minji, Jinyong Jun, and Hyein Chang. 2016. "Perceived Discrimination, Acculturation, Acculturative Stress, and Depression among North Korean Refugees: A Mediated Moderation Model(차별지각, 문화적응, 문화적응 스트레스가 북한이탈주민의 우울에 미치는 영향)." Korean Journal of Woman Psychology 21(3): 459-481.

Lee, Soon Min and Woochan Shim. 2018. "An Analysis of Trends in Quantitative Studies on Female North Korean Refugees(탈북여성 관련 양적 연구동향 분석)." Journal of the Korea Contents Association 18(7): 470-483.

Lee, Woo Young. 2016. "“Arduous March and the Mind of North Korean People:

The State's Account of the March." The Korean Journal of Unification Affairs 28(1): 173-203.

Lee, Young Jin and Hae Won Kim. 2019. "Association of Traumatic Events, Post Traumatic Stress Disorder and Sexual Autonomy among Female University Students of North Korean Defectors(북한이탈 여대생의 외상경험, 외상 후 스트레스장애와 성적 자율성의 관련성)." Korean Journal of Women 
Health Nursing 25(1): 46-59.

Lim, Hyun-Ju, Lee Guna, and Yang Sook-Ja. 2017. "The Trends in Research on the Health of North Korean Refugees(북한이탈주민의 건강 관련 연구 동 향)." Journal of Korean Academy of Community Health Nursing 28(2): 144-155.

Moon, Gaeul, Bora Park, Eunsil Lee, Gyuyeon Choi, Jeongjae Lee, Imsoon Lee, and Joonhwan Lee. 2015. "The Health Conditions of the North Korean Women Defectors and the Marriage Immigrant Women(탈북여성 및 결혼 이주여성 건강 실태 조사)." Journal of the Korean Society of Maternal and Child Health 19(1): 103-109.

Moon, Ok Ryun, Ji Eon Baek, Dong Sik Kim, and Chul Hyung Lee. 2004. "Comparison of North \& South Korea Using Anthropometric Measurements of North Korea Detectors - North Korean Detectors at an Educational Institute(Hanawon) in South Korea." Journal of Korea Association of Health Promotion 2(2): 127-136.

Park, Hyerim. 2019. "A Study on Food Supply Quantity and Main Food Sources of Nutrient in North Korea(북한의 식품 공급량 및 영양소 주요 급원식 품에 대한 연구)." (Master's dissertation, Ewha Womans University).

Park, Jung Ran and Dong Wan Kang. 2011. "A Study on Female North Korean Defectors: Trends, Controversial Issues, and Tasks(탈북여성 연구: 동향, 쟁점, 과제)." North Korean Studies Review 15(2): 1-24.

Park, Jung Ran and Dong Wan Kang. 2011. "A Study on the Marriage and Family Relationships of Female North Korean Defectors from a Feminist Perspective: With a Focus on Changes to Individual Levels of Acculturation in a Migration Process(탈북여성 결혼의 젠더구조와 문화적응 고찰: 정체성, 경제,건강수준을 중심으로)." Locality and Globality: Korean Journal of Social Sciences 35(2): 39-63.

Park, Sang Min and Haewon Lee. 2013. "Current Status of Healthcare and Effective Health Aid Strategies in North Korea(북한의 보건의료 현황과 효율적 지원방안)." Journal of the Korean Medical Association 56(5): 368-374.

Park, Sang Min, Haewon Lee, and Bo Hyun Kim. 2014. "Status of Mother-child Health in North Korea and Effective Aid Strategies(북한 모자보건 현황 과 효율적 지원방안)." KDI Review of the North Korean Economy 16(8): 3-15.

Park, Sun Young. 2000. "An Assessment of the Long - Term Effects of Food Crisis on Children's Growth and Development in North Korea(북한 식량 위기의 장기적 영향 평가: 인체의 성장발육과 건강에 미치는 영향과 그 사회적 함의)." Korean Cultural Anthropology 33(1): 207-240.

Rhee, Young Sun, Hye Wan Ku, and In Young Han. 2011." Systematic Reviews of North Korean Refugees: Women`s Distinguishable Experience(학술논 
문분석을 통해 본 북한이탈주민 여성의 특수성)." The Korean Journal of Unification Affairs 23(2):147-194.

Rhee, Young Sun, Hye Wan Ku, and In Young Han. 2013. "Factors Related to Female Sexual Dysfunction of North Korean Women Defectors(북한이탈 주민 여성의 성기능 실태 및 영향요인)." Korean Journal of Health Education and Promotion 30(2): 55-69.

Ro, Eun-hee, and Insoo Oh. 2018. "A Study on Counseling and Educational Interventions for North Korean Defector's Children Born in the Third Countries: Focused on School Based Mental Health Program(제3국 출생 북한이탈주민 자녀를 위한 상담 및 교육적 개입방안 : 학교기반 정신건 강 프로그램을 중심으로)." The Korean Journal of Unification Affairs 30(2): 227-264.

Sim, Kyoung-bo. 2018. "Study on the Characteristics and Quality Level of Single Subject Researches in the Stroke Patients: The Field of Health Care" The Journal of Korean Society of Community Based Occupational Therapy 8(2): 15-28.

Shin, Hee Young. 2015. Expecting South-North Co R\&D in Public Health to Become One Axis of Creative Economy (Health Industry Trend, June Issue: 보건의료 R\&D 남북공동 연구 창조경제 한 축 기대). Osong, Korea: Korea Health Industry Development Institute.

Shin, Hye Won, Ji Hyun Kim, Ja Hyung Lee, and Yae Young Kim. 2007. "A

Review of Health Care Systems and Women's Health Status of North Korea(북한의 보건의료와 여성건강상태에 관한 고찰)." Health \& Nursing 19(1): 44-54.

Shin, Nanhee. 2019. "Trends and Prospects of the Oral Studies About the North Korean Migrants: Focusing on North Korean Migrant Women(탈북이주 민 구술연구의 동향과 전망: 탈북이주여성을 중심으로)." The Journal of Humanities and Social Science 10(4): 195-210.

Shim, Jae Eun, Ji Hyun Yoon, Seong Yeon Jeong, Mi Na Park, and Yeon Sook Lee. 2007. "Status of Early Childhood and Maternal Nutrition in South Korea and North Korea(남북한 영유아 및 가임기 여성의 영양상태 비 교)." Korean Journal of Community Nutrition 12(2): 123-132.

Suh, Seong Hyuk, Shin Seung Hwan, and Byung Wook You. 2015. "The Study about Health-Related Fitness and Quality of Life in North Korean Female Refugees(새터민 여성의 건강관련 체력과 삶의 질에 관한 연구)." Journal of the Korean Society for Wellness 10(1): 311-321.

The Institute for Peace Affairs. 2009. 10 Years of Hanawon: Established as a Resting Place for the North Korean Refugees. Tongil Hankook 308: 87.

Um, Taewan. 2012. "Relationships of Social Capital, Community Integration, and Depression in Female Saeteomins(새터민 여성의 사회적 자본 및 지역사회 통합과 우울의 관계)." Health and Social Welfare Review 32(3): 92-121. 
Wee, Hyeseung. 2018. "The Impact of Famine on Body Size: Analysis of Height by Cohort of North Korean Defectors(기근이 신체에 미친 효과: 북한 이 탈주민의 키를 통해 살펴본 코호트별 분석)." Korean Health Economic Review 24(4): 123-143.

Yang, Ok-Kyung and Ji-Hye Yun. 2017. "Scoping Review on the Mental Health Studies of North Korean Detectors in Korea(북한이탈주민의 정신건강 연구 동향 분석: 스코핑 고찰 방법을 중심으로)." Multiculture \& Peace 11(2): 172-196.

Yong, Young Suk and Suk Ja Kim. 2018. "Analysis of Research Trends on North Korean Defector Children(탈북 아동에 관한 연구 동향 분석)." Korean Journal of Child Studies 39(4): 23-37.

Yoon, Yeosang, Sung Chul Park and Soon Hee Im. 2014. Status of Infringement of Human Rights Due to Forced Repatriation of North Korean Defectors in China. Seoul, Korea: North Korean Human Rights Information Center.

Yun, Soh-Yoon, Young Hye Kwon, and Ji Hyun Yoon. 2016. "Status of Maternal Nutrition in South and North Korea(남북한 가임기 여성의 영양상태 비 교)." Korean Journal of Community Nutrition 21(3): 265-273. 


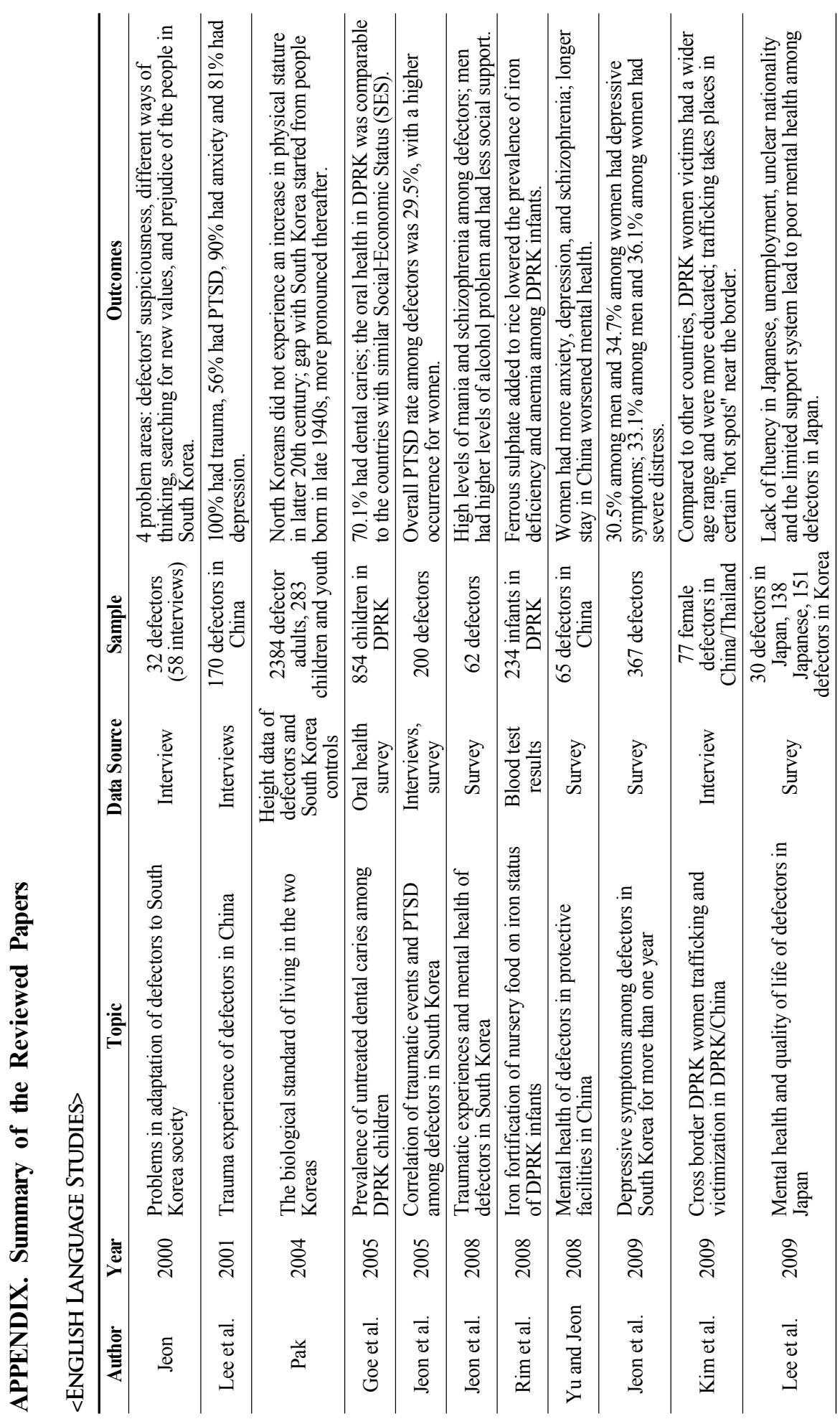




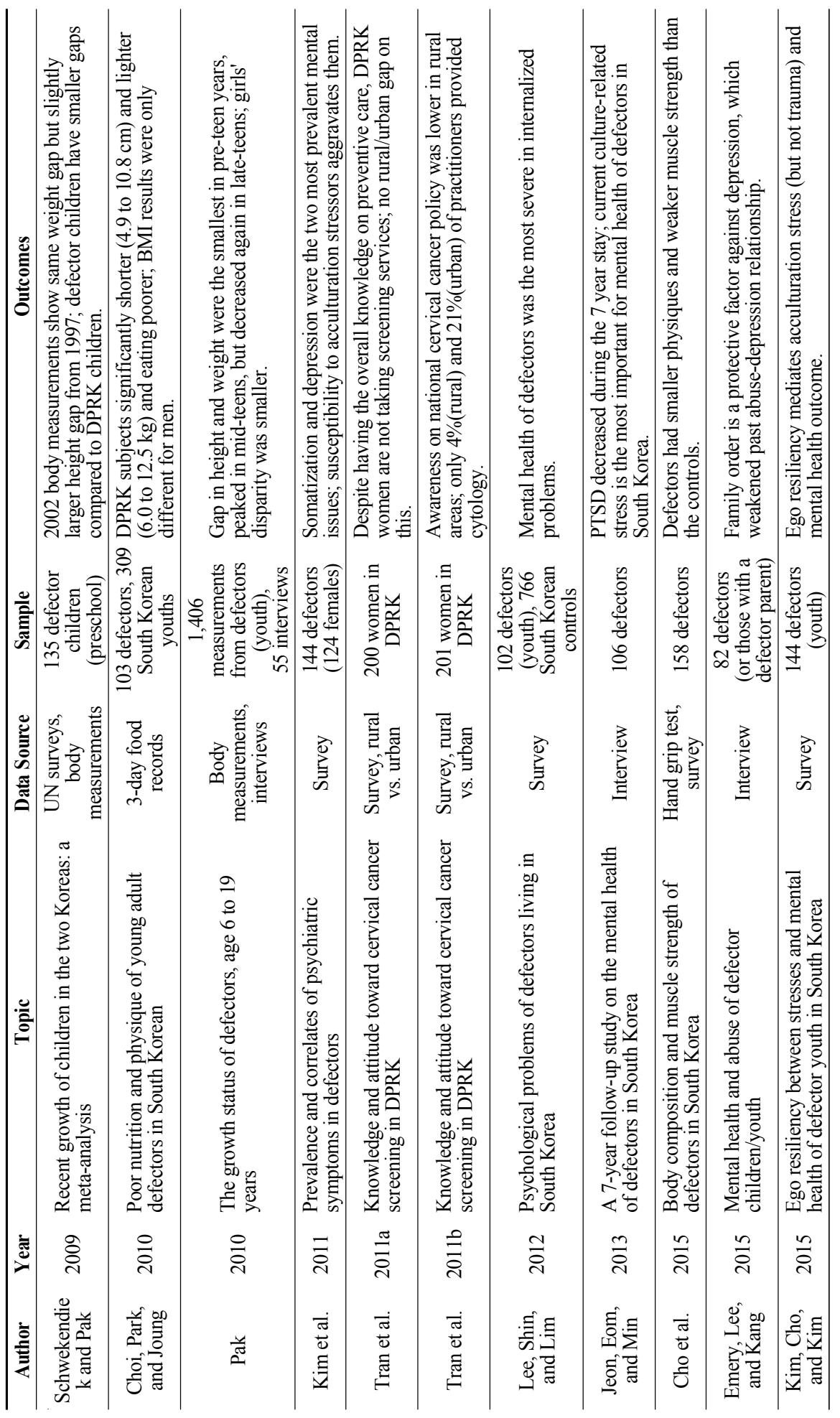




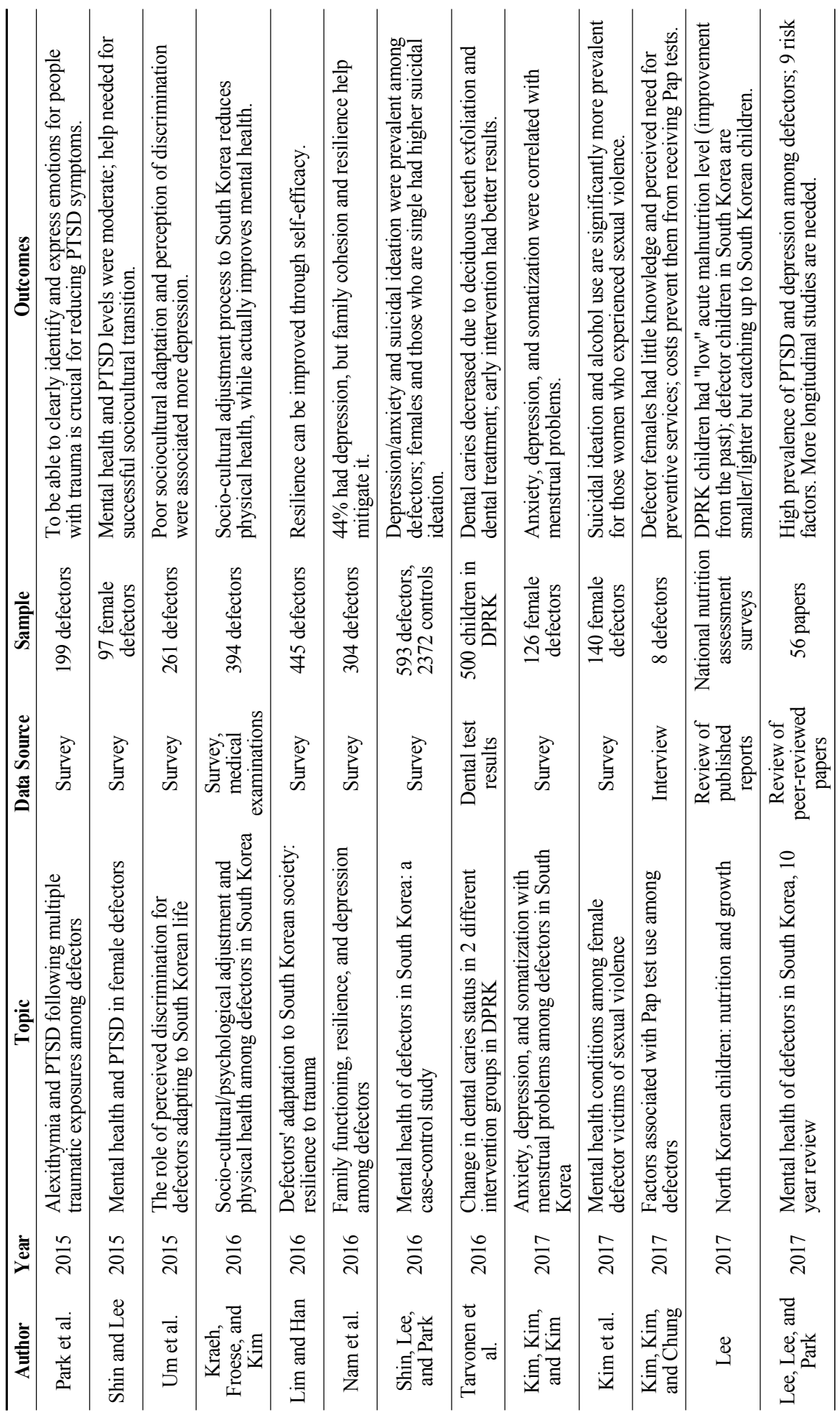




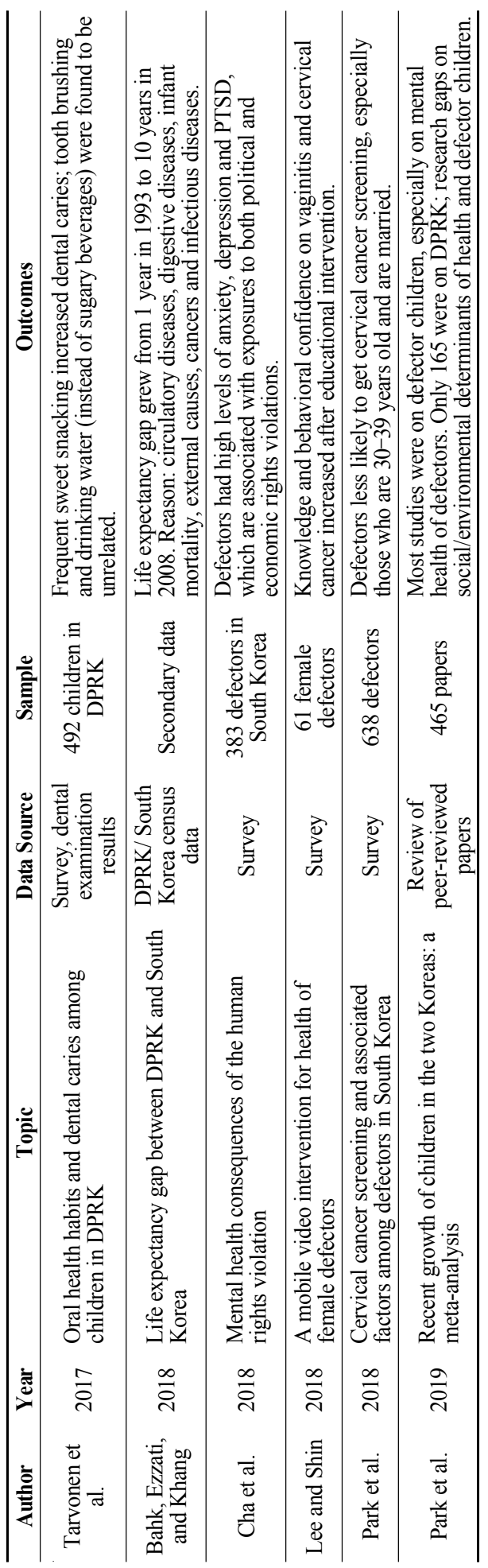




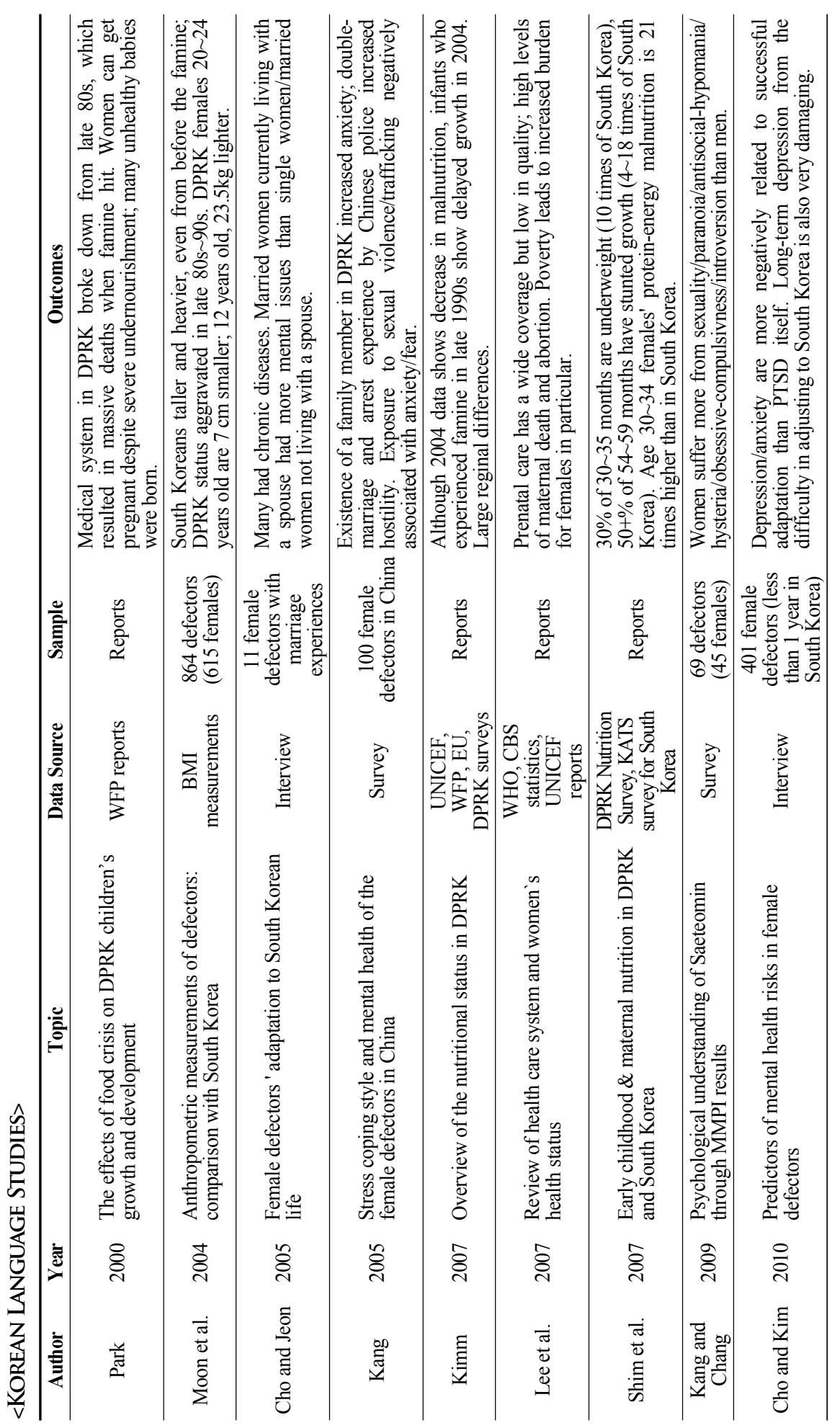




\begin{tabular}{|c|c|c|c|c|c|c|c|c|c|}
\hline 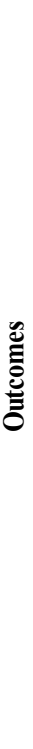 & 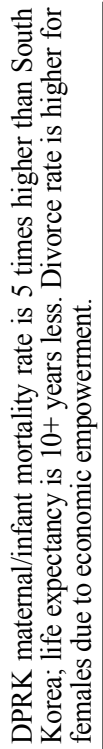 & 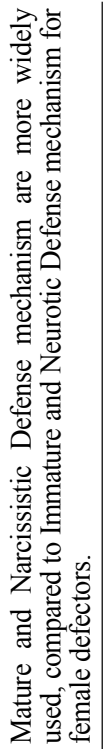 & 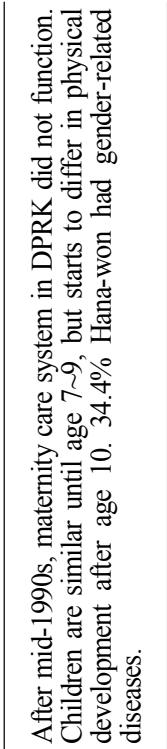 & 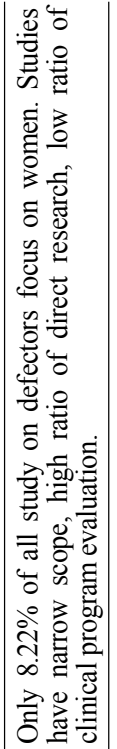 & 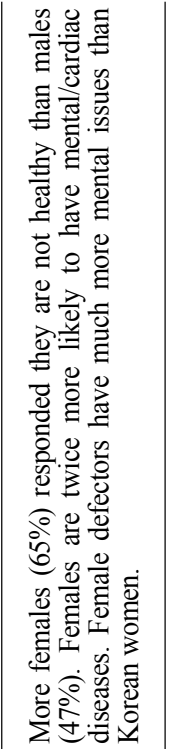 & 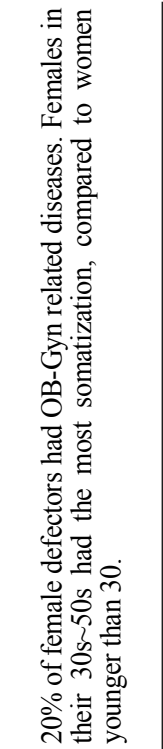 & 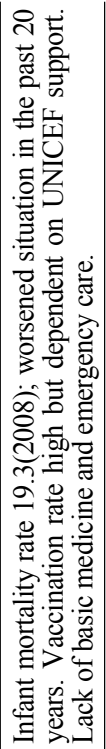 & 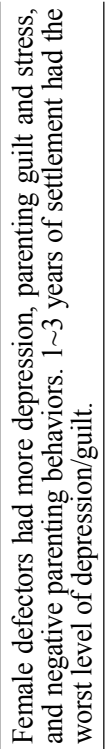 & 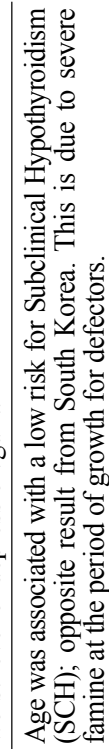 \\
\hline & $\begin{array}{l}\stackrel{n}{0} \\
\stackrel{0}{0} \\
\tilde{2}\end{array}$ & 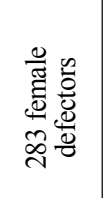 & 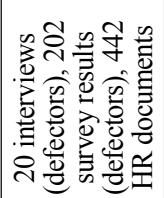 & 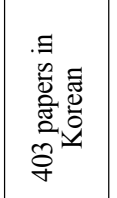 & 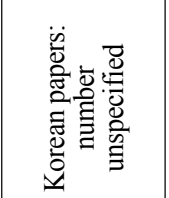 & 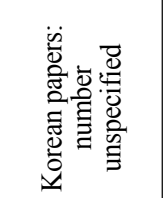 & $\frac{n}{0}$ & 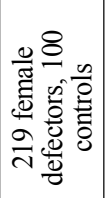 & 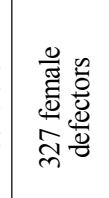 \\
\hline 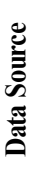 & 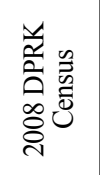 & 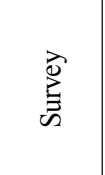 & 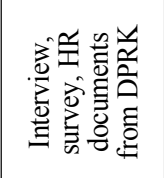 & 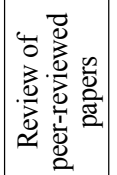 & 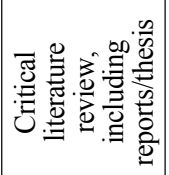 & 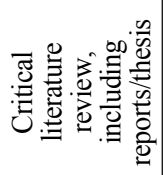 & 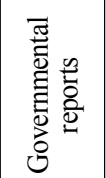 & $\stackrel{\vec{\partial}}{\stackrel{\vec{b}}{0}}$ & 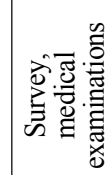 \\
\hline है & 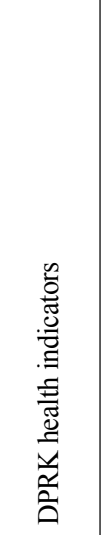 & 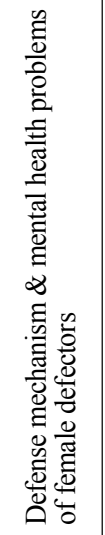 & 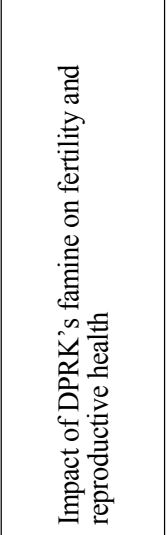 & 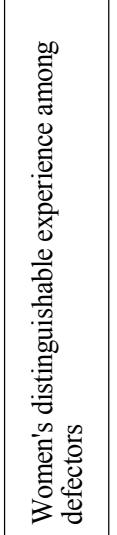 & 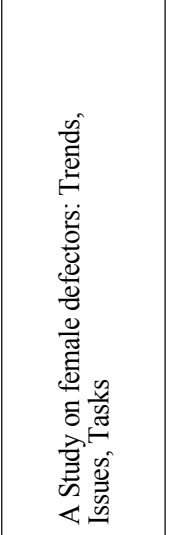 & 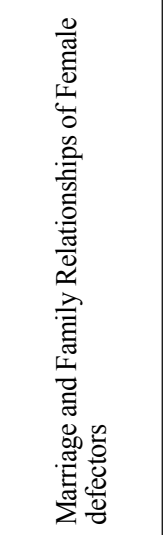 & 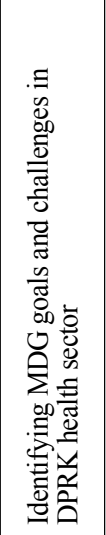 & 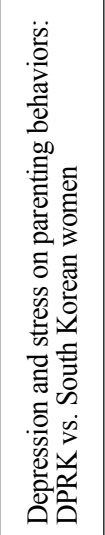 & 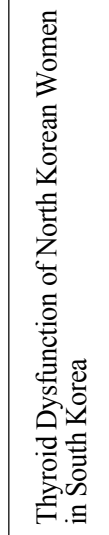 \\
\hline$\underset{\nu}{\grave{\Xi}}$ & $\stackrel{\circ}{\circ}$ & $\stackrel{\circ}{\stackrel{0}{\circ}}$ & $\stackrel{\circ}{\stackrel{\circ}{\circ}}$ & $\overline{\vec{D}}$ & $\overline{\vec{D}}$ & $\overline{\vec{\sim}}$ & $\stackrel{\sim}{\stackrel{\sim}{*}}$ & $\stackrel{\sim}{\stackrel{\sim}{*}}$ & $\frac{\sim}{\stackrel{\sim}{d}}$ \\
\hline 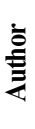 & $\begin{array}{l}\text { 照 } \\
\text { 营 }\end{array}$ & 进 & 慁 & 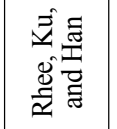 & 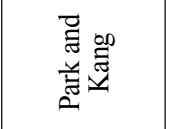 & 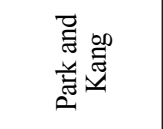 & $\begin{array}{l}\text { 胞 } \\
\text { 营 } \\
\end{array}$ & 运 & 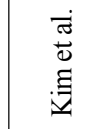 \\
\hline
\end{tabular}




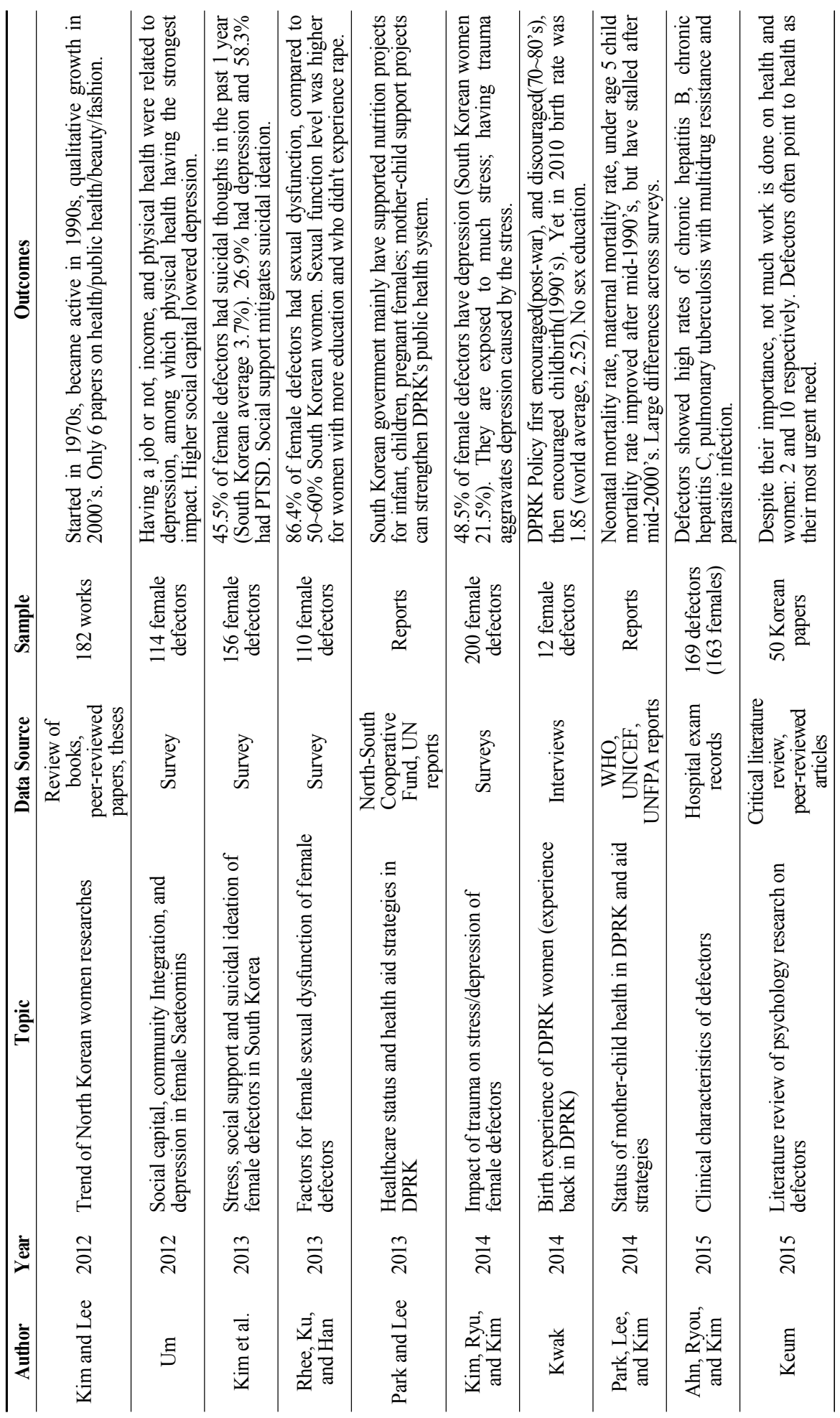




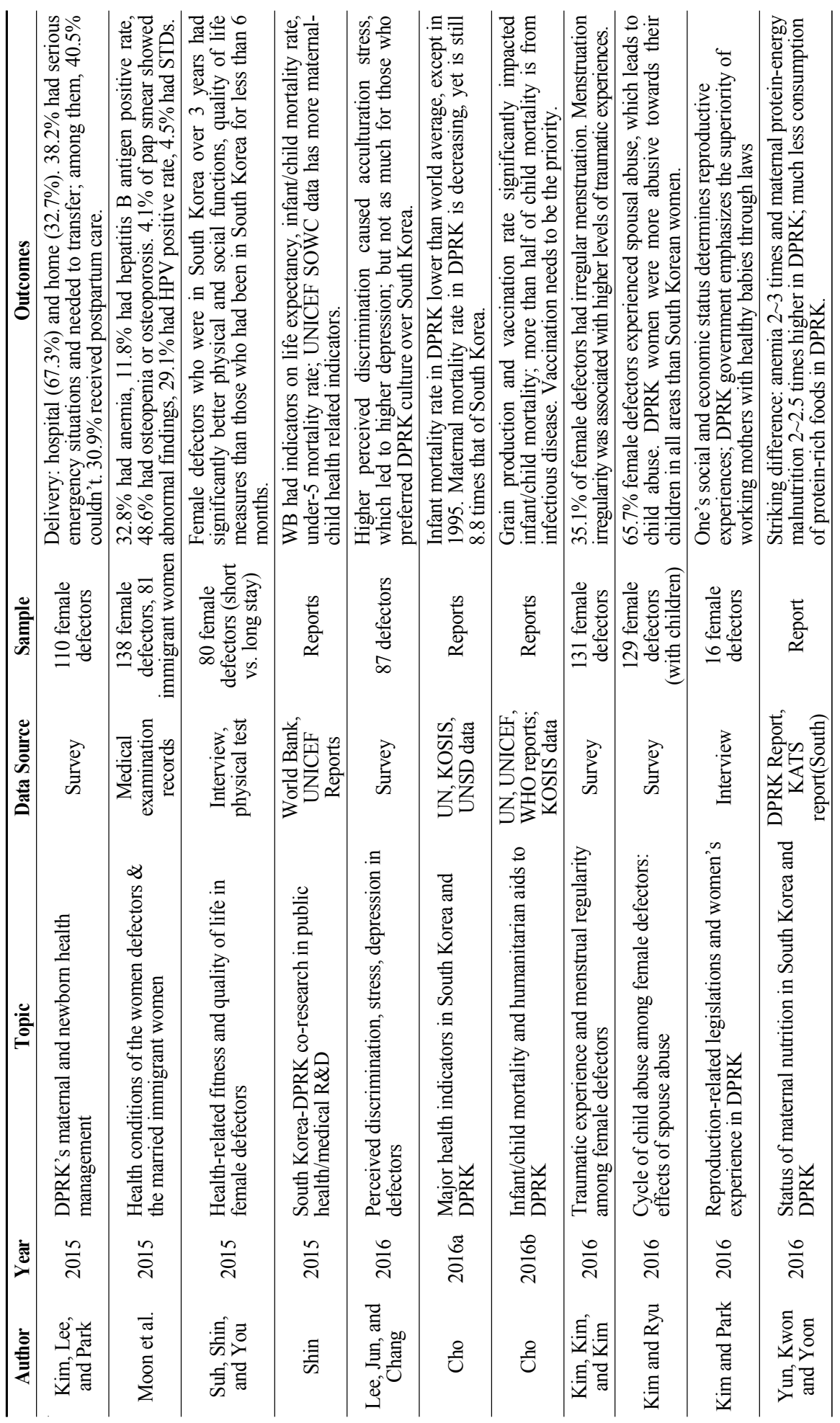




\begin{tabular}{|c|c|c|c|c|c|c|c|c|c|c|}
\hline 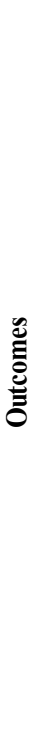 & 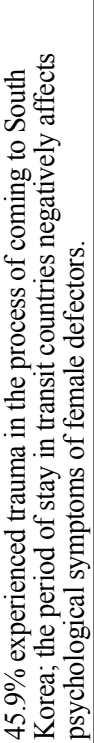 & 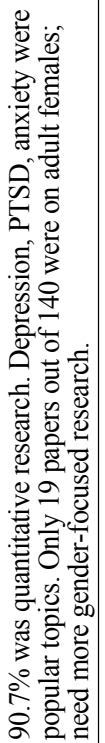 & 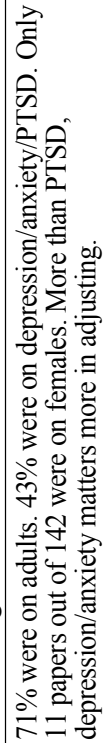 & 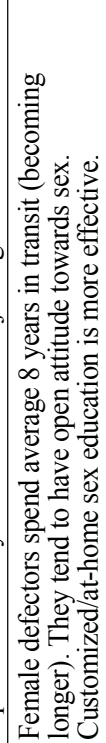 & 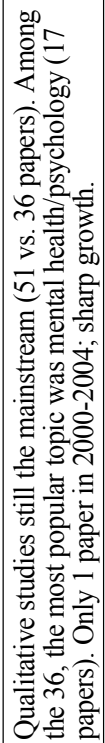 & 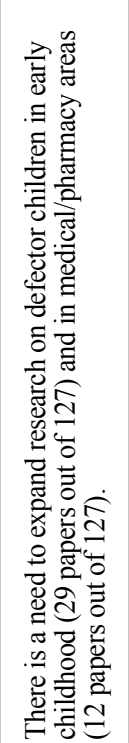 & 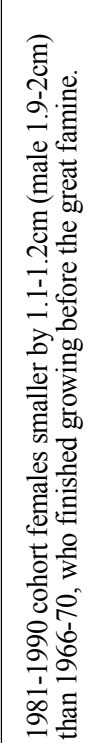 & 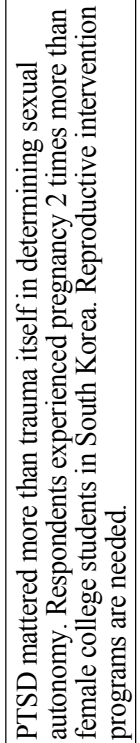 & 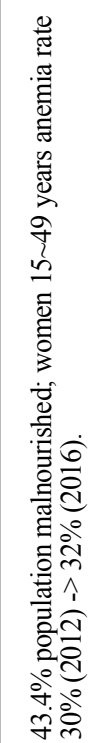 & 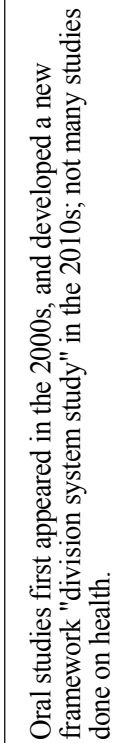 \\
\hline 总 & 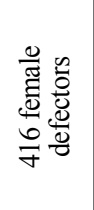 & 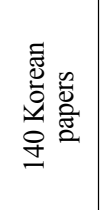 & 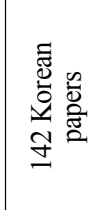 & 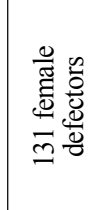 & 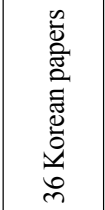 & 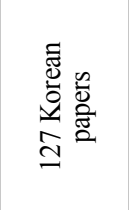 & 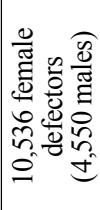 & 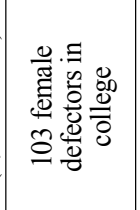 & 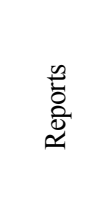 & 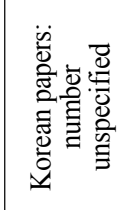 \\
\hline 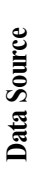 & 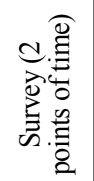 & 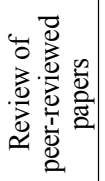 & 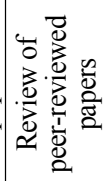 & 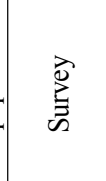 & 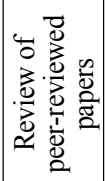 & 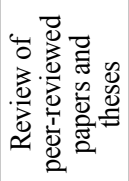 & 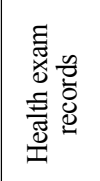 & $\stackrel{\grave{\partial}}{\grave{c}}$ & 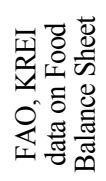 & 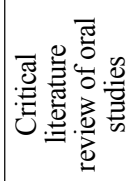 \\
\hline 。 & 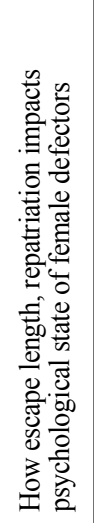 & 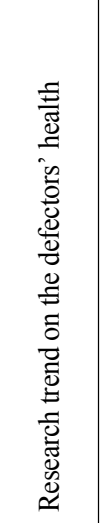 & 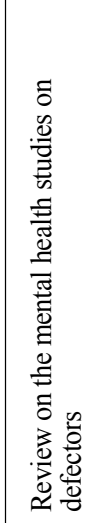 & 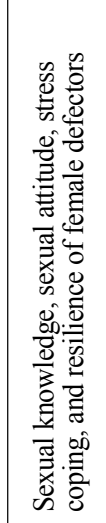 & 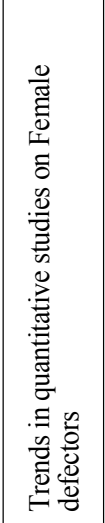 & 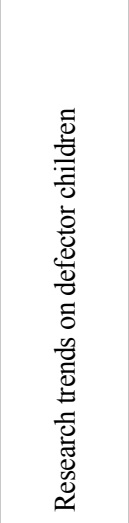 & 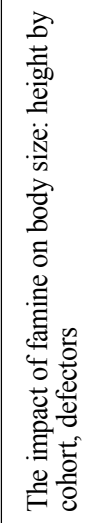 & 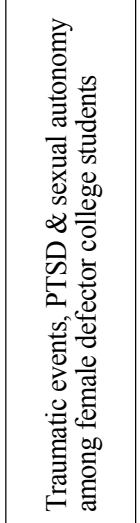 & 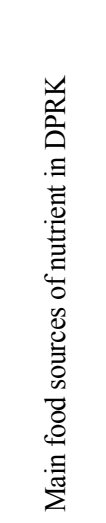 & 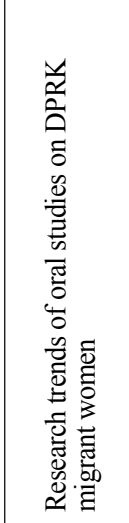 \\
\hline$\Xi$ & $\overline{\vec{d}}$ & $\overrightarrow{\stackrel{\sim}{\circ}}$ & 혹 & $\stackrel{\infty}{\stackrel{\infty}{\sim}}$ & $\stackrel{\infty}{\stackrel{\infty}{\sim}}$ & $\stackrel{\infty}{\stackrel{\infty}{*}}$ & $\stackrel{\infty}{\stackrel{\infty}{ }}$ & $\stackrel{\circ}{\stackrel{\partial}{i}}$ & $\stackrel{\stackrel{\partial}{\vec{d}}}{ }$ & $\stackrel{\curvearrowright}{\vec{\partial}}$ \\
\hline 童 & 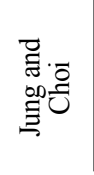 & 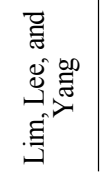 & 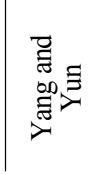 & $\begin{array}{l}\bar{\sigma} \\
\tilde{\omega} \\
\tilde{0} \\
\stackrel{0}{0}\end{array}$ & 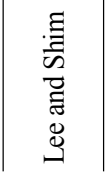 & 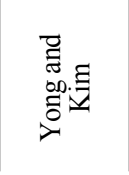 & ${ }_{3}^{8}$ & 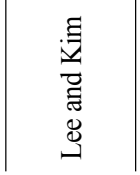 & 离 & क \\
\hline
\end{tabular}




\section{ENDNOTES}

${ }^{1}$ Hanawon is the settlement support center for North Korean refugees run by the Ministry of Unification. Since its establishment in July 1999, it has been running a 12-week program aimed at helping the refugees adjust to the life in South Korea. Its curriculum include education on capitalism and market economy, basic job training and improve emotional stability (The Institute for Peace Affairs 2009).

2 The great famine, also known as the "Arduous March" period, refers to the severe poverty DPRK experienced in 1996-2000. There is some controversy over how many passed away during this time, but more recent statistics from KOSIS estimates the number to be around 330,000 (Lee 2016). According to Lee (2011), 300,000 is a conservative estimate, and some sources claim even 3 million deaths, when including the indirect effects of the famine (Lee 2011, 23). 